\title{
THE ARCHITECTURE OF BIAS: DEEP STRUCTURES IN TORT LAW
}

\author{
Martha Ghamallas $\dagger$
}

Gender and race have disappeared from the face of tort law. The old doctrines that explicitly limited recovery exclusively to one gender have been either abolished or extended on a gender-neutral basis. Women as well as men may now recover for such claims as loss of spousal consortium ${ }^{1}$ and loss of a child's services. ${ }^{2}$ The disabilities

† Professor of Law, University of Pittsburgh. I am especially indebted to Jody Armour for his many insights and questions that contributed so much to this manuscript. Special thanks as well to Anne Schiff, Peter Shane, Lu-in Wang, Lester Olson, Katherine Franke, Karla Fischer, Leslie Bender, and the participants of the feminism and critical race workshop at the University of Arizona. I also benefited from comments from colleagues attending the critical perspectives panel of the AALS Torts Conference organized by Deborah Merritt. Finally, I would like to thank Douglas Scott, my research assistant, for his hard work, critical analysis, and quantitative expertise.

At common law, only the husband had a cause of action for loss of consortium when his wife suffered a nonfatal injury. The husband's claim was originally for loss of his wife's services, likened to the master's claim for loss of his servant's services in cases where the servant suffered physical injury. The husband's claim was gradually expanded to include recovery for the "three Ss": loss of sex, society, and services. Beginning in the $1950 \mathrm{~s}$, most states expanded the claim on a gender-neutral basis to permit wives to recover for losses they sustained when their husbands were injured. See W. Page Keeton et al., Prosser and KeEton on the LaW of TORTS 931-32 (5th ed. 1984); WEX S. MALONE, TORTS IN A NUTSHELL 56-57 (1979) (discussing the rights of husbands and wives to recover losses suffered through injuries to their spouses). The most pressing issue today is whether courts should further expand the claim to unmarried intimates, including same-sex couples who are not permitted to marry. See, e.g., Elden v. Sheldon, 758 P.2d 582, 588-90 (Cal. 1988) (denying loss-of-consortium claim to unmarried cohabitants).

${ }^{2}$ As the "head and master" of the household, the father was originally the only parent allowed to sue for the loss of his child's services. The father's claim for services was an outgrowth of his right to custody of unemancipated children. Mothers had a right to recover when their children were negligently injured only if the father was dead or had abandoned the family, or if the parents had never married. See MALONE, supra note 1, at 57-58 (discussing a parent's right to recover losses suffered through injury to a child). Today, in those states that recognize the claim for loss of a child's consortium, including the intangible elements of loss of companionship, society, and affection, the claim is generally accorded to both parents. See, e.g., Shockley v. Prier, 225 N.W.2d 495, 501 (Wis. 1975) (recognizing that both parents of an injured minor "may maintain a cause of action for loss of aid, comfort, society and companionship"); KEETON ET AL., supra note 1, at 934-35 (noting that the courts have shown 
that prevented slaves, free persons of color, ${ }^{3}$ and married women ${ }^{4}$ from filing suit on their own behalf and giving testimony in court have been lifted by legislation guaranteeing access to the courts. Juries are now integrated, and even peremptory challenges may no longer be exercised on the basis of race ${ }^{5}$ or gender. ${ }^{6}$

But as in so many other areas of the law, formal equality on the face of the law of torts bears little connection to gender and race equity as measured by real-world standards. Most empirical studies indicate that women of all races and minority men continue to receive significantly lower damage awards than white men in personal injury and wrongful death suits. ${ }^{7}$ Some of these data have been generated by the movement to study gender and race bias in the courts, ${ }^{8}$ with the predominant focus being on disparities between men and

"considerable willingness" in recent years to allow both parents to recover for loss of a child's consortium).

${ }^{3}$ The Civil Rights Act of 1866 first addressed civil disabilities that had excluded blacks from the protection of the civil courts. It guaranteed that "[a]ll persons ... shall have the same right in every State and Territory to make and enforce contracts, to sue, be parties, give evidence, and to the full and equal benefit of all laws and proceedings for the security of their persons and property as is enjoyed by white citizens." 42 U.S.C. $\$ 1981$ (a) (1994).

4 The doctrine of marital unity or coverture suspended women's legal identity during marriage. With few exceptions, married women could not sue in their own right and were dependent on their husbands' legal initiatives on their behalf. See 1 WILLIAM BLACKSTONE, COMMENTARIES *430-31 (discussing feme-covert, the incorporation of a woman's "legal existence" into her husband's, and its effect on a woman's right to sue). Gradually, in the mid-19th century, states passed Married Women's Property Acts and earnings statutes, which afforded a measure of legal autonomy to women. See Richard H. Chused, Married Women's Property Law: 1800-1850, 71 GEO. L.J. 1359, 142324 (1983); Reva B. Siegel, Home as Work: The First Woman's Rights Claims Concerning Wives' Household Labor, 1850-1880, 103 YALE L.J. 1073, 1112-205 (1994) (tracing the development of marital joint-property laws in 19th-century America); see also Richard $\mathrm{H}$. Chused, Late Nineteenth Century Married Women's Property Law: Reception of the Early Married Women's Property Acts by Courts and Legislatures, 29 AM. J. LEGAL HIST. 3, 8-30 (1985) (discussing the legal history of Oregon's married women's property laws).

${ }^{5}$ See, e.g., Edmonson v. Leesville Concrete Co., 500 U.S. 614, 631 (1991) (barring race-based peremptories in civil trials).

${ }^{6}$ See, e.g., J.E.B. v. Alabama ex rel. T.B., 511 U.S. 127, 146 (1994) (barring genderbased peremptories as violative of equal protection).

See infra notes 10-13 and accompanying text.

${ }^{8}$ State and federal task forces on gender and race bias in the courts have focused attention on inequities in tort law, particularly with respect to damages and other areas often neglected by torts scholars. The final reports of these task forces represent a body of practical scholarship that integrates feminist theory, empirical research, and advocacy for reform. See NINTH CIRCUIT GENDER BIAS TASK FORCE, THE EFFECTS OF GENDER IN THE FEDERAL CoURTS (1993), reprinted in 67 S. CAL. L. REV. 745, 949-62 (1994); Judith Resnik, Asking About Gender in Courts, 21 SiGNS 952, 955-77 (1996) (discussing various studies analyzing the effects of gender in the courts). 
women. ${ }^{9}$ These data confirm that in the realm of torts a higher value is placed upon the lives of white men and that injuries suffered by this group are worth more than injuries suffered by other less privileged groups in society.

For example, my calculations from tort judgments and settlements reported in a 1996 guide for personal injury lawyers indicate that, in the aggregate, male plaintiffs received awards that were twenty-seven percent higher than those of female plaintiffs. ${ }^{10}$ Similarly, a study of wrongful death cases between 1984 and 1988 conducted by the Washington State Task Force on Gender and Justice in the Courts found that the mean damage award for a male decedent was $\$ 332,166$, compared to a mean award of $\$ 214,923$ for a female

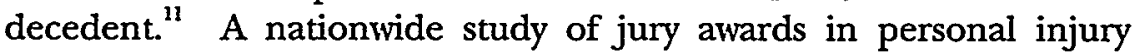
cases, conducted by Jury Verdict Research, Inc., showed that in virtually all age groups, women received significantly lower mean and median compensatory damage awards than did men. ${ }^{12}$ Although there

${ }^{9}$ The empirical data are not very refined. Most gender bias task force reports include data broken down only by gender, without also sorting for race. The racial bias studies typically use only two racial categories, white and black. Thus, separate attention is not consistently paid to the situation of minority women and racial groups other than African-Americans. The most recent U.S. Government report on earnings includes a breakdown by gender and breaks down "race" to include the census categories of white, black, Hispanic-origin, and Asian and Pacific Islanders. It includes no separate listing for other ethnic groups. See BUREAU OF THE CENSUS, U.S. DEP'T OF COMMERCE, MONEY INCOME IN THE UNITED STATES: 1995, at ix (1995) (comparing income by "selected characteristics").

${ }^{10}$ The 27\% figure was calculated by totaling the 1995-1996 awards and settlements recorded across 28 categories of specific types of injuries (from abdominal to wrist injuries, including wrongful death). See WHAT's IT WORTH? A GUIDE TO CURRENT Personal Injury Awards and SetTlements (James P. Munger ed., 1996). The database created from this compilation consists of 1200 summaries of decisions and settlements taken from court reports and from publications of the American Trial Lawyers Association from April 1995 to March 1996. It represents an unrefined measure that does not control for severity of injury within categories, for age, occupation, or educational attainment of the plaintiff, or for other factors that might influence the size of the award. Nevertheless, my point here is simply to document a gross disparity in overall compensation between men and women.

"WASHINGTON STATE TASK Force ON Gender and JUSTICE IN the Courts, GENDER AND JUSTICE IN THE COURTS 89-90 (1989) (listing Washington statistics for wrongful death jury awards for men and women).

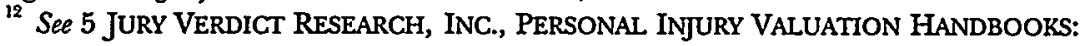
THE AGED AS PLAINTIFFs, pts. I \& II (1987), cited in ILIINOIS TASK FORCE ON GENDER BIAS IN THE COURTS, THE 1990 REPORT $181 \mathrm{n} .3$ (1990) [hereinafter ILIINOIS TASK FORCE]. The only age groups in which women did not fare poorly compared to men were plaintiffs aged 60-64 and over 80. See id.; see also JAMES N. DERTOUZOS ET AL., RAND CORPORATION, THE LEGAL AND ECONOMIC CONSEQUENCES OF WRONGFUL 
are fewer data analyzing tort awards along racial lines, a Washington study of asbestos cases in the 1980s found substantial disparities between settlement amounts of minority and nonminority plaintiffs. ${ }^{13}$

Recently, scholars have focused on specific elements of damage awards, including punitive damages ${ }^{14}$ and damages for loss of future earning capacity, ${ }^{15}$ in an attempt to pinpoint the source of the gender and race disparities. This Article has a more theoretical focus. It represents my search to uncover the dominant value structures, or hierarchies, in tort law that have worked to the disadvantage of women of all races and minority men. These deep structures are cognitive in nature and operate within a system that is facially neutral with respect to gender and race. I contend that, most often, bias finds its way into the law, not through explicit differential treatment of men and women or racial minorities and whites, but through reliance on implicit hierarchies of values and dichotomous thinking.

Throughout this Article, I employ a broad definition of bias, by which I hope to capture those habits of mind and practices that are most effective in reproducing the inequities of the status quo. In this Article, bias includes both deliberate and unconscious disparities in the treatment of persons who are similarly situated, whether stemming from animus, hostility, insensitivity, lack of empathy, or the use of stereotypes or unfair generalizations about a group. In addition to disparate treatment, I use the term bias to include practices, doctrines, or policies that have a disproportionately harmful effect on a group and cannot be justified by reference to other competing interests or concerns. My definition of bias thus includes both intentional (i.e., disparate treatment) and unintentional (i.e., disparate impact) bias and focuses on both the state of mind of the actor and the effect on the victim. Most importantly, bias herein encompasses what might

TERMINATION 31 (1988) (showing considerably lower wrongful termination awards for women, even after controlling for current salary levels).

15 See WASHINGTON STATE MINORITY AND JUSTICE TASK FORCE, FINAL REPORT 123-25 (1990) (comparing minority and nonminority settlements for various injuries); see also AUDREY CHIN \& MARK A. PETERSON, RAND CORPORATION, DEEP POCKETS, EMPTY POCKETS: WHO WINS IN COOK COUNTY JURY TRIAIS 40 (1985) (finding that, in cases involving white defendants, awards for African-Americans in state and federal jury trials totaled only $74 \%$ as much as awards for white plaintiffs for the same injury).

${ }^{14}$ See Thomas Koenig \& Michael Rustad, His and Her Tort Reform: Gender Injustice in Disguise, 70 WASH. L. REV. 1, 3-10 (1995) (analyzing the nature of the injuries for which punitive damages are sought by men and women).

${ }^{15}$ See Martha Chamallas, Questioning the Use of Race-Specific and Gender-Specific Economic Data in Tort Litigation: A Constitutional Argument, 63 FORDHAM L. REv. 73, 75 (1994) (arguing that the uncritical use of statistical data keyed to race and gender has led to dramatically lower damage awards for women and minorities). 
be termed cognitive bias, by which I mean the use of categories that are themselves shaped or contaminated by confining stereotypes and habitual ways of thinking about nondominant groups in our society.

For the most part, this definition of bias tracks legal concepts of discrimination, especially those employed in employment discrimination litigation. However, because I focus so prominently on unconscious and nondeliberate kinds of bias, I sometimes go beyond traditional meanings of discrimination to highlight inequities that would not be actionable under prevailing constitutional and antidiscrimination doctrine. This broad definition of bias seems particularly appropriate in evaluating tort law. In constructing the common law, judges and juries are not confined to avoiding illegalities, but are expected to reach for fairness and an equitable accommodation of interests. The "public policy" dimension of tort law is broad enough to include the goal of advancement of gender and race justice, in addition to promoting such values as economic efficiency, ease of judicial administration, or common standards of morality.

My primary contention is that contemporary tort law devalues or undervalues the lives, activities, and potential of women and people of color. Applying critical theory, I argue that this devaluation is accomplished by subtle means, through the social construction of legal categories that purport to describe types of injuries and types of damages. I look for the hidden gender or racial dimension in basic legal categories, such as "physical harm" or "pecuniary loss." When these "neutral" categories of injuries and damages are ranked in importance, there is often a negative impact on nondominant groups. Specifically, I assert that injuries of low value are more often associated with women, while injuries of high value are more often linked to men. The devaluation process can also work to contaminate the very neutrality of the categories themselves. My research suggests that the gender of the victim plays an important role. In deciding how to categorize a loss, the law looks not only in some abstract way at the nature of the injury or loss, but also at who is suffering the loss. In this way, the gender of the prototypical plaintiff affects how we conceptualize the nature of the harm.

This Article is informed by concepts in antidiscrimination law, principally the theory of discrimination known as "disparate impact" liability. ${ }^{16}$ My approach also draws heavily upon both feminist theory

${ }^{16}$ Disparate impact liability is premised on the harmful effects of a policy or action on a traditionally disadvantaged group. Typically, the employer or other defendant 
and critical race theory. From these areas, I import the notion of gender-linked and race-linked devaluation of harm. This type of bias is central to my contention that the deep cognitive structures in tort law are not neutral and that basic tort categories carry hidden gender and racial associations.

Part I of this Article explains what I mean by devaluation. I look at the concept of devaluation generally, drawing from criminal law and employment law, as well as from the torts context. I offer examples of devaluation of the lives, activities, and potential of women and people of color in cases where there may be no disparate treatment of individuals. I focus on these three contexts because they bear an obvious relevance to cognizable injuries in tort law.

The rest of the Article is devoted to speculation as to how this devaluation is accomplished in the law of torts. I focus predominately on gender devaluation and its possible effects on diverse groups of women. My starting point is an assertion about the architecture of contemporary tort law. In Part II, I claim that there is a widespread, if tacit, acceptance of a hierarchy of types of injuries and types of damages. Although we do not always tell our students about this on the first day of class, tort law values physical injuries and property damage more highly than emotional injuries or relational harms. More recently, another hierarchy has emerged which complements, but does not duplicate, the hierarchy of types of injuries. This implicit hierarchy of damages values pecuniary losses (e.g., wage loss and medical expenses) over nonpecuniary losses (e.g., pain and suffering, mental distress, and lost companionship and society). These two implicit hierarchies of value appear neutral because they are not explicitly tied to any gender or racial group. They have power to influence our thought, moreover, precisely because they are taken for granted and not often subjected to scrutiny by the courts or scholars.

The apparent neutrality of the tort hierarchies of value, however, does not produce a system that is equal or symmetric in results. To

will be required to justify the harmful policy by proving that it is necessary for the business and related to the requirements of the job. Proof of invidious motivation or intent is not necessary because it is the unjustified harmful effect that is the harm to be remedied. Originally a judicial invention, disparate impact claims have since been endorsed and codified in the Civil Rights Act of 1991. See 42 U.S.C. $\S 2000 \mathrm{e}-2(k)(1)$ (1994). For recent discussions of disparate impact theory, see Barbara Flagg, Fashioning a Title VII Remedy for Transparently White Subjective Decisionmaking, 104 YALE L.J. 2009, 2031-38 (1995) (discussing the adequacy and breadth of Title VII); Ramona L. Paetzold \& Steven L. Willborn, Deconstructing Disparate Impact: $A$ View of the Model Through New Lenses, 74 N.C. L. REV. 325, 364-77 (1996) (discussing "blindered causation" as the defining characteristic of the disparate impact model). 
borrow a Title VII concept, the hierarchies have a disproportionate negative impact on women. In Part III of this Article, I offer three examples of such disparate impact on women. The first two result from privileging physical harm over relational and emotional harm. The third exemplifies how the preference for pecuniary over nonpecuniary losses harms women. I argue that it is appropriate to regard the tort law hierarchies of values as "gendered" because over time they tend to produce and reproduce gender disparities both in the types of legally recognized injuries and in the value placed on certain losses.

The fourth and final Part focuses on the origin of gendered hierarchies and asks how the gender correlation is maintained under a legal regime ostensibly committed to gender equality. At this juncture, I use critical theory to suggest the existence of a conceptual vicious cycle as a possible mechanism for reproducing gender bias. This cycle is a process of devaluation. The vicious cycle works to forge a cognitive connection between basic types of injuries and damages on the one hand and gender on the other. The categories that describe types of injuries and types of damages are dualistic; the dominant discourse in torts is cast in terms of physical versus emotional injuries or pecuniary versus nonpecuniary losses. We then map onto these dualisms corresponding gender labels, associating women with emotional injury and nonpecuniary harm. The final step in the process of devaluation is perceptual: We are apt to perceive and categorize injury sustained by women as emotional or nonpecuniary, even when the injury could logically also be characterized as physical or as having pecuniary value. The vicious cycle is then complete: Emotional harm and nonpecuniary loss are devalued because of their cognitive association with women, and the harm that women suffer is more likely to fall into one of the disfavored "female" categories. On a material level, operation of the vicious cycle thus perpetuates lower awards for women because their losses are more likely to rank lower on the hierarchy.

Because devaluation affects the construction of categories, not simply individuals, men whose lives and activities follow "female" patterns are also disadvantaged. The conceptual vicious cycle may have an ideological dimension as well, insofar as it functions to discount the importance of women's suffering as measured in the civil justice system. By so privatizing women's suffering, the law quietly repro- 
duces the gendered public/private split ${ }^{17}$ at a time when tort law is most often criticized for favoring plaintiffs and exaggerating the significance of their losses.

\section{DEVALUATION AS A GENERAL CONCEPT}

For lawyers and law students, the most easily understood kind of discrimination is what is known as disparate treatment. The Equal Protection Clause has been interpreted to reach only this kind of discrimination, ${ }^{18}$ and it so dominates legal discourse that it is sometimes mistaken for the only conceivable form of discrimination. Simply stated, disparate treatment consists of conduct that intentionally targets individuals for unfavorable treatment because of their race, gender, or other personal characteristics. ${ }^{19}$ Thus, the equal protection principle would be violated if men but not women were allowed to recover for certain defined injuries or if a judge or jury deliberately based its decision to deny relief on the individual plaintiff's race or gender.

The focus of this Article, however, is on devaluation, rather than disparate treatment. Devaluation is a kind of bias that does not always attach itself directly to the individual asserting legal rights or defending against legal prosecution. It instead affects value judgments, such as those made about the seriousness of certain conduct or the importance of an activity. There is a crucial connection between these value judgments and race and gender: To the extent that conduct is cognitively associated with women or racial minorities, it descends in importance. That is why devaluation is justifiably counted as a form of bias. However, an important distinction between devaluation and ordinary disparate treatment is that devaluation is not directly depend-

${ }^{17}$ For discussions of how the false dichotomy between the public and private spheres harms women, see Frances E. Olsen, The Family and the Market: A Study of Ideology and Legal Reform, 96 HARV. L. REV. 1497, 1527-30 (1983) (noting that sharp conceptual distinctions between market and family limit our thinking and legal reforms); Nadine Taub \& Elizabeth M. Schneider, Women's Subordination and the Role of Law, in THE Pourmics OF LAW 151, 151-76 (David Kairys ed., rev. ed. 1990).

${ }^{18}$ The Supreme Court first rejected Title VII's disparate impact analysis for use in equal protection cases in Washington v. Davis, 426 U.S. 229, $246-48$ (1976). After Davis, challengers were required to prove discriminatory purpose and show that the decisionmaker acted "at least in part 'because of,' not merely 'in spite of,' its adverse effects upon an identifiable group." Personnel Adm'r v. Feeney, 442 U.S. 256, 279 (1979).

19 See International Bhd. of Teamsters v. United States, 431 U.S. 324, 348-55 (1977) (distinguishing disparate treatment from disparate impact in Title VII cases). 
ent on a particular actor's race or gender. Once a category is devalued, all individuals within that category feel the effects of devaluation. Even the male receptionist, for example, loses prestige for doing a woman's job. ${ }^{20}$

The discussion that follows examines the processes of devaluation generally, before focusing exclusively on tort law and the devaluation of types of injuries and types of damages associated with women and racial minorities. The examples are intended to show how seemingly neutral conceptual constructs, such as crimes or jobs, may become linked cognitively to a particular gender or race and how this process affects judgments about relative worth.

\section{A. Devaluation of Black Life}

A dramatic illustration of devaluation involves the operation of the criminal justice system in death penalty cases. A large-scale empirical study done by Professor David Baldus for the NAACP Legal Defense Fund showed that, in Georgia, defendants charged with killing white victims were 4.3 times more likely to receive a death sentence than defendants charged with killing blacks, even after 230 nonracial variables, such as the brutality of the crime and other aggravating factors, were taken into account. ${ }^{21}$ Using the same model, the study found that the race of the defendant was a far less important factor than the race of the victim: Black defendants were only 1.1 times as likely to receive a death sentence as other defendants. ${ }^{22}$

The findings of the Baldus study highlighted the harsh reality that the lives of whites have greater value in our society than the lives of blacks: The taking of white lives merits stiffer punishment. ${ }^{23}$ Using

${ }^{20}$ See infra notes 39, 49-51 and accompanying text (discussing the relationship between the prototypical holder of a given position and the status that attaches to that position).

${ }^{21}$ The Baldus study was at the center of an unsuccessful equal protection challenge to imposition of the death penalty in McClesky v. Kemp, 481 U.S. 279, 291-99 (1987). The study is discussed in DAVD C. BALDUS ET AL., EQUAL JUSTICE AND THE DEATH PENALTY (1990).

${ }_{22}$ See McClesky, 481 U.S. at 287. The combined factors of the race of the victim and the race of the defendant did, however, correlate with the decision to seek the death penalty. The raw data indicated that the prosecutor sought the death penalty in $70 \%$ of the cases involving a black defendant and a white victim, $32 \%$ of the cases involving a white defendant and a white victim, $15 \%$ of the cases involving a black defendant and a black victim, and $19 \%$ of the cases involving a white defendant and a black victim. See id.

${ }^{23}$ For other studies finding a similar race-of-the-victim effect in capital cases, see U.S. Gen. Accounting Office, Death Penalty Sentencing, in Report to the 
the statistical technique of multiple regression analysis, the study was able to quantify the importance of the "race of the victim" factor in a subjective decisionmaking process and to tease out cognitive bias. The study showed how bias likely affected the evaluation of the seriousness of the crime, with the effect of devaluing black life relative to white life. This race-linked devaluation differs from ordinary disparate treatment in that the race effect was not traceable solely to the race of the defendant. If the focus had only been on the treatment of the criminal defendants and whether they deserved the death penalty, the system might have appeared more race-neutral.

Race-linked devaluation is a less recognizable form of discrimination that is likely to stem from unconscious judgments and nondeliberate mental associations. ${ }^{24}$ Imagine, for example, a white juror sitting in a criminal case who sincerely wishes to make an unbiased judgment based on the facts. If both the defendant and the victim are black, the juror might never consider the possibility that race could play a role in her judgment. She might never ask herself whether her gut feeling is somehow affected by racial stereotypes or other assumptions about the worth of the victim. Few lawyers would make an appeal like that found in the motion picture $A$ Time to Kill, based on John Grisham's novel by the same name, in which the lawyer asked the white jurors to counteract the "race of the victim" effect by imagining that the victimized black child was white instead of black. ${ }^{25}$ Rather, the racial factor is more likely to remain unaddressed and undetected.

SENATE AND HOUSE COMMITTEES ON THE JUDICIARY 130, 135 (1990) (noting that the fact that the victim was white influenced the decision to seek the death penalty in $82 \%$ of 28 studies reviewed); Raymond Pasternoster, Prosecutorial Discretion in Requesting the Death Penalty: A Case of Victim-Based Racial Discrimination, 18 L. \& Soc'Y REV. 437, 471 (1984) (describing a South Carolina study finding that prosecutors are more likely to seek the death penalty if the victim is white).

${ }^{24}$ The most frequently cited article on the topic of unconscious racism is Charles R. Lawrence III, The Id, the Ego, and Equal Protection: Reckoning with Unconscious Racism, 39 STAN. L. REV. 317 (1987).

${ }^{25}$ A TIME TO KILL (Warner Bros. 1996). Professor Jody Armour has argued that biased judgments based on ingrained stereotypes may sometimes be counteracted if the decisionmaker is alerted to the operation of the racial factor and urged to reexamine his or her judgment. See Jody Armour, Stereotypes and Prejudice: Helping Legal Decisionmakers Break the Prejudice Habit, 83 CAL. L. REv. 733, 759-60 (1995) ("Reminding decisionmakers of their personal beliefs ... may help them to resist falling unconsciously into the discrimination habit."). Some lawyers representing African-American clients alert prospective jurors to the race of the parties in an attempt to warn them that unconscious racism might affect their judgments. See Frank M. McClellan, The Dark Side of Tort Reform: Searching for Racial Justice, 48 RUTGERS L. REV. 761,780 (1996) (recounting one lawyer's voir dire inquiry about jurors' possible bias). 
The harms of race-linked devaluation may also be harder to articulate than those stemming from ordinary disparate treatment. In the capital punishment context, for example, if the race of the defendant influences the verdict, a specific black defendant will be slated for execution under circumstances in which his white counterpart would escape that fate. When the race of the victim influences the judgment, however, the individual and collective harms are visited upon persons other than the criminal defendant. The refusal to impose the harshest penalty for the taking of black lives may mean that black communities are less safe, if one assumes that the death penalty operates as a deterrent to homicide. More certain is that the family and friends of the undervalued black victim will suffer emotional harm from believing that justice was not served. Most importantly, the greater societal tolerance for violence inflicted on blacks reinforces a cultural belief in the inferiority of blacks and generally contributes to the maintenance of white supremacy. Borrowing from Dean Paul Brest's classic analysis of the multiple rationales for the antidiscrimination principle, ${ }^{26}$ Professor Randall Kennedy has described the phenomenon of disparate sentencing based on the race of the victim as "racially selective empathy": "the unconscious failure to extend to [blacks] the same recognition of humanity, and hence the same sympathy and care, given as a matter of course to [whites]. "'27

The devaluation of black lives does not confine itself to capital cases, but extends to criminal sentencing in noncapital cases. ${ }^{28}$ In

${ }^{26}$ See Paul Brest, The Supreme Court, 1975 Term-Foreword: In Defense of the Antidiscrimination Principle, 90 HARV. L. REV. 1 (1976).

${ }^{27}$ Randall L. Kennedy, McCleskey v. Kemp: Race, Capital Punishment, and the Supreme Court, 101 HARV. L. REV. 1388, 1420 (1988) (quoting Brest, supra note 26, at 7-8).

${ }^{23}$ Studies evidencing such bias are collected in Developments in the Law-Race and the Criminal Process, 101 HARV. L. REv. 1475, 1525-28 (1988), which describes a number of studies of racial discrimination in both prosecutorial assessment decisions and postassessment charging decisions. Published mainly in the eariy 1980s, these studies document disparities based on the race of the victim and the race of the defendant, with the race of the victim being a more important factor. See WiLliam J. BowErS ET AL., LEGAL HOMICIDE 340-44 (1984) (finding that race of defendant and victim affected probability of obtaining first-degree murder indictment); William J. Bowers \& Glenn L. Pierce, Arbitrariness and Discrimination Under Post-Furman Capital Statutes, 26 CRIME \& DELINQ. 563, 614 (1980) (noting that "blacks who kill whites are most likely to be charged with an accompanying felony"); Gary D. LaFree, The Effect of Sexual Stratification by Race on Official Reactions to Rape, 45 AM. SOC. REV. 842, 847-48 (1980) (reporting that black men who assaulted white women were more likely to be charged with a felony); Martha A. Myers \& John Hagan, Private and Public Trouble: Prosecutors and the Allocation of Court Resources, 26 Soc. PROBS. 439, 446 (1979) (finding that the race of the victim affects the decision to charge); Michael L. Radelet \& Glenn $\mathrm{L}$. Pierce, Race and Prosecutorial Discretion in Homicide Cases, 19 L. \& SOC'Y REV. 587, 615-19 
cases of violent crimes not amounting to homicide, devaluation means that the health and physical well-being of black victims and black communities fail to receive the same measure of protection given to white victims and white communities. ${ }^{29}$

It is reasonable to suppose that race-linked devaluation of the lives of minority victims also operates within the civil justice system. Particularly because tort law is specially designed to fix a specific value on the life of the decedent in a wrongful death case and to quantify a plaintiff's loss in a personal injury case, there is no escaping the need for the factinder to make an evaluation. Thus, race-linked devaluation potentially affects the heart of the torts process by posing a threat to the fair adjudication of a central issue in the litigation.

\section{B. Devaluation of Women's Activities}

The most adequately theorized example of the devaluation process as it affects women and their activities is found in the theory of comparable worth. Comparable worth theory was developed to address the problem of the sizable disparity in earnings between male and female workers. ${ }^{30}$ For quite some time, sociologists and feminist scholars $^{31}$ had contended that a large portion of the wage gap was

(1985) (reporting that a charge is more likely to be upgraded in crimes involving a white victim and a black defendant).

${ }^{29}$ Cf. Kennedy, supra note 27, at 1391 (describing devaluation theory as "community-oriented").

${ }^{30}$ The wage gap has narrowed in recent years, but is still sizable. In 1986, women's hourly median earnings were $70 \%$ of men's. See SARAH M. EvaNS \& BARBARA J. NELSON, WAGE JUSTICE: COMPARABLE WORTH AND THE PARADOX OF TECHNOCRATIC REFORM 43 (1989). This looked like a dramatic improvement over $59.3 \%$, the figure reported in 1980, with which most people were familiar (from the phrase "sixty cents on the dollar"). See id. The $59 \%$ figure, however, represented median yearly wages for full-time, year-round, white workers. See id. The comparable 1986 figure for all women's yearly wages compared to all men's yearly wages was only $65 \%$. See id. at 43 44. One researcher estimates that approximately one-third of the gender pay gap would close if employers adopted traditional job-evaluation plans for pay equity purposes. See BARBARA R. BERGMANN, THE ECONOMIC EMERGENCE OF WOMEN 194 (1986).

${ }^{31}$ Sociologist Jerry Jacobs explains that only in the last 20 years have sociologists begun to question the "status attainment" framework that had dominated research on inequality. See Jerry A. Jacobs, Introduction to GENDER INEQUALITY AT WORK 1, 3-4 (Jerry A. Jacobs ed., 1995) [hereinafter GENDER INEQUALITY AT WORK]. That framework had sought to "delineate the connections between the occupational status of fathers and sons." Id. at 3. Because it omitted women from the framework, the statusattainment approach did not reveal that "[g]ender inequality [was] not reducible to social class" and that sex segregation of jobs and occupations was more important to explain the gender wage gap. Id. at 3-4; see also BERGMANN, supra note 30, at 123-45 
traceable to the high degree of gender segregation in jobs. ${ }^{32}$ These two phenomena have been particularly resistant to change, remaining largely unaffected by the passage of the Equal Pay Act and Title VII. ${ }^{33}$ There was growing recognition that reducing the wage gap necessarily entailed the raising of wage rates in predominantly female jobs. ${ }^{34}$ From its inception in the early 1980s, the strategy behind comparable worth focused directly on devaluation. Unlike ordinary disparate treatment claims which center on denying women access to traditionally male jobs, comparable worth claims seek to revalue female jobs and thereby improve conditions for both women and men in these jobs. $^{35}$

Comparable worth theory rests on the proposition that work perceived as women's work has been downgraded and that the value of work performed in predominantly female jobs-by male and female workers alike-is systematically underrated, given the relative skill, effort, and responsibility involved. ${ }^{36}$ Comparable worth advocates have relied on job-evaluation techniques that measure the worth of a job to an employer, beyond simply relying on the market wage. ${ }^{37}$ Studies

("The key to the low wages attached to women's jobs is the occupational segregation within a high proportion of workplaces.").

${ }^{32}$ The 1990 census revealed that the labor market is still characterized by a high degree of sex segregation. Skilled trade jobs continue to be heavily dominated by men (e.g., only one in 58 carpenters is a woman; one in 20 welders is a woman). See Katherine M. Franke, The Central Mistake of Sex Discrimination Law: The Disaggregation of Sex from Gender, 144 U. PA. L. REv. 1, 87 (1995) (citing statistics taken from the 1990 U.S. Census). The professions are more integrated but still are identifiably male (e.g., $79 \%$ of physicians are men; $87 \%$ of dentists are men; $76 \%$ of lawyers are men). See id. at 88. For a listing and breakdown of job categories by gender, see $i d$. at 87-88. Most women continue to work in low-paying, low-mobility, largely segregated jobs. See WOMEN'S BUREAU, U.S. DEP'T OF LABOR, 20 LEADING OCCUPATIONS OF EMPLOYED WOMEN 1990 ANNUAL AVERAGES (1991). Almost half of all women workers are employed in occupations that are at least $80 \%$ female. See WOMEN'S WORK, MEN's WORK 7 (Barbara F. Reskin \& Heidi I. Hartmann eds., 1986).

${ }^{33}$ See EVANS \& NELSON, supra note 30, at 16 \& n.* (noting that despite antidiscrimination measures in the 1960 s and early 1970s, the wage gap between male and female workers remained roughly the same).

${ }^{34}$ Jobs that are at least $70 \%$ female are typically characterized as "female" jobs. See Ruth G. Blumrosen, Wage Discrimination, Job Segregation and Title VII of the Civil Rights Act of 1964, 12 U. MICH. J.L. REFORM 397, 461 n.236 (1979) (citing N. WILLIS, COMPARABLE WORTH STUDY: PHASE II (1976)).

${ }^{35}$ See infra notes 49-51 and accompanying text.

${ }^{26}$ See EVANS \& NELSON, supra note 30, at 7-8 (" [C]omparable worth is a wage policy requiring equal pay within a jurisdiction or firm for male- and female-, majority- and minority-dominated job classifications that are valued equally... regardless of the sex or race of job incumbents. ${ }^{\text {) }}$.

${ }^{37}$ For a discussion of job-evaluation techniques, see BERGMANN, supra note 30 , at 180-86 (discussing pay-equity evaluations); Deborah L. Rhode, Occupational Inequality, 
done of public jobs in several states document the existence of substantial disparities in pay-most often on the order of approximately twenty percent-between comparable predominantly male and predominantly female jobs. ${ }^{38}$ Notably, the more intensely women dominate an occupation, the greater the disparity in wages for both men and women workers in that job category. ${ }^{39}$

The theoretical significance of comparable worth theory is its core contention that women's work is regarded as less important, justifying a lower wage scale. It is the gender of most of the job holders, rather than the intrinsic demands of the work, that influences its place on the job hierarchy. According to Ruth Blumrosen, one of the earliest comparable worth scholars, a vicious cycle operates to perpetuate lower wages for women and minority workers:

It is not only that the jobs into which women and minorities have been traditionally segregated are lower paying jobs, but it is that they are lower paying, in part at least, because they are the jobs which have been reserved for minorities and women. The social, historical, and economic studies have demonstrated the high degree of likelihood that the jobs of minorities and women are considered to be of lesser worth because they are female or minority jobs, and the analysis of both job evaluation and the general method of setting wages has established how this value judgment is applied in the setting of wages.

The conceptual vicious cycle as it affects wage rates provides an explanation for the phenomenon of job shifting-the lowering of pay

1988 DUKE L.J. 1207, 1228-30 (reviewing the relative- and intrinsic-worth approaches). Like the market, however, job-evaluation techniques are not free of gender bias. See Ronnie J. Steinberg, Gendered Instructions: Cultural Lag and Gender Bias in the Hay System of Job Evaluation, in GENDER INEQUALITY AT WORK, supra note 31, at 57, 58 ("Even after conceptions about gender have changed, job evaluation systems of earlier eras may transport outdated criteria into the new labor market contexts.").

${ }^{33}$ See American Fed'n of State, County \& Mun. Employees v. Washington, $578 \mathrm{~F}$. Supp. 846, 864 (W.D. Wash. 1983) (finding a "deliberate perpetuation of an approximate $20 \%$ disparity in salaries between predominately male and predominately female job classifications with the same number of job evaluation points"), rev'd, $770 \mathrm{~F} .2 \mathrm{~d}$ 1401 (9th Cir. 1985); ALICE H. COOK, INDUSTRIAL RELATIONS CTR. OF THE UNIV. OF HAW. AT MANOA, COMPARABLE WORTH: THE PROBLEM AND THE STATES' APPROACHES TO WAGE EQUITY 80-81 (1983) (discussing Wisconsin's statistics); Nina Rothchild, Toward Comparable Worth: The Minnesota Experience, 2 YALE L. \& POL'Y REV. 346, 354-55 (1984) (noting a National Organization for Women study which found "staggering" wage inequalities between women and men).

${ }^{39}$ See COMMITTEE ON OCCUPATIONAL ClASSIFICATION \& ANALYSIS, NATIONAL RESEARCH COUNCIL, WOMEN, WORK, AND WAGES: EQUAL PAY FOR JOBS OF EQUAL VALUE 28 n.13 (Donald J. Treiman \& Heidi I. Hartmann eds., 1981) ("[O]n the average each additional percent female of an occupation costs male workers about $\$ 30$ in annual income and female workers about $\$ 16 \ldots .$. ).

${ }^{10}$ Blumrosen, supra note 34 , at $455-57$. 
or prestige when a particular job or occupation changes from being male-dominated to female-dominated. The best known examples involve cross-cultural comparisons: Being a physician is a high status, high paying job in the United States, where men dominate the field; in Russia, where most doctors are women, the job carries less prestige and money. ${ }^{41}$ In the United States, this shifting phenomenon took place over time in the occupations of secretary and bank teller, which lost prestige when women entered and began to dominate the field. ${ }^{42}$ The gender shift from male to female may take place when work becomes degraded by routinization or mechanization. ${ }^{43}$ Or the devaluation may occur simply when the field becomes integrated, even when no change at all occurs in the nature of the tasks. Thus, the influential research of Barbara Reskin and Patricia Roos explains that feminization has occurred in fields that have already started to deteriorate in status. ${ }^{44}$ What might superficially look like gender integration might be better viewed as male "flight" from fields with decreasing pay and opportunity. For example, starting in the 1970s, the gender composition of sociology as an academic field began to change. ${ }^{45}$ Women's representation markedly increased at a time when federal funding for research declined, real earnings decreased, and unemployment rose. ${ }^{46}$

A similar phenomenon has occurred within occupations. There is evidence of resegregation of particular jobs such that segregated enclaves develop within seemingly integrated occupations. For ex-

11 See Cynthia Fuchs Epstern, Deceptive Distinctions: Sex, Gender, AND the SOCIAL ORDER 152 (1988) (noting that, although women constitute a high percentage of doctors in Russia, they are confined to the lowest-level jobs in that profession and denied access to the higher-ranking academic positions); Kaisa Kauppinen et al., Medical Doctors in Moscow-Their Work, Family and Well-Being, in WOMEN's VOICES IN RUSSIA TODAY 164, 165-66 (Anna Rotkirch \& Elina Haavio-Mannila eds., 1996) (stating that the proportion of female doctors in Russia from 1980 to 1990 has ranged from $77 \%$ to $68 \%$ ).

${ }^{42}$ See Barbara F. Reskin \& Patricia A. Roos, Job Queues, Gender Queues: EXPLAINING WOMEN'S INROADS INTO MALE OCCUPATIONS 11-15 (1990) (explaining the feminization of clerical positions due to decline in earnings, mobility, and job autonomy).

13 See Catharine mackinnon, Sexual harassment of Working Women 12 (1979) (arguing that automated jobs tend to become defined as "women's work").

11 RESKIN \& ROOS, supra note 42, at 11-15 (arguing that women entered positions vacated by men due to the deterioration in the fields).

${ }^{15}$ See Patricia A. Roos \& Katharine W. Jones, Shifting Gender Boundaries: Women's Inroads into Academic Sociology, in GENDER INEQUALITY AT WORK, supra note 31, at 297, 303.

${ }^{15}$ See id. at 308-15. 
ample, women's influx into pharmacy has been confined largely to the retail sector, while men work in the more lucrative and more prestigious commercial, research, and academic settings. Women in real estate are in residential sales, while men dominate commercial real estate. ${ }^{47}$ The effect is that women's work is still identifiable and still underpaid compared to the more elite male-dominated sectors. ${ }^{48}$

Comparable worth theory addresses gender-linked devaluation, as opposed to ordinary disparate treatment. Because male workers in predominantly female jobs are also disadvantaged by gendered wage rates, the harm (depressed wages) and the sex of the job holder are not connected in a direct, individualistic way. Sociologists call the theoretical model underlying comparable worth the "status composition hypothesis." One researcher explains the hypothesis in this way:

The status composition hypothesis is that jobs that are disproportionately female or male become stereotyped, and the work process itself begins to reflect the social value of the master status of typical incumbents. This is not an argument about discrimination against individuals but against jobs. The argument is that jobs and organizational structure may be fundamentally influenced by gender.

We can best understand comparable worth theory as challenging the cognitive association between women's work and work of low value. Like the race-linked devaluation uncovered by the Baldus study, ${ }^{50}$ the injury unearthed by comparable worth theory is collective in nature, affecting the group of workers (male and female) who work in undervalued jobs and occupations. The undervaluation is not traceable to the sex of the individual job holder, but rather to the sex of the prototypical job holder.

The courts have not accepted comparable worth as a theory of liability under Title VII. In the mid-1980s, a few influential decisions in the lower courts ${ }^{51}$ had the effect of halting the filing of comparable

${ }^{47}$ See Barbara F. Reskin, Bringing the Men Back In: Sex Differentiation and the Devaluation of Women's Work, 2 GENDER \& SOC'Y 58, 68-71 (1988).

${ }^{18}$ See Jo Anne Preston, Gender and the Formation of a Women's Profession: The Case of Public School Teaching, in GENDER INEQUALITY AT WORK, supra note 31, at 379, 396 (discussing the historical study of male domination of elite sectors of teaching).

${ }^{19}$ Donald Tomaskovic-Devey, Sex Composition and Gendered Earnings Inequality: $A$ Comparison of Job and Occupational Models, in GENDER INEQUALITY AT WORK, supra note 31 , at 23,29 (citations omitted).

${ }^{50}$ See supra text accompanying notes 23-25.

51 The two most important cases were Spaulding $v$. University of Washington, 740 F.2d 686, 706-08 (9th Cir. 1984), which held that disparate impact theory could not be used to challenge the employer's reliance on market wages, and American Federation of State, 
worth claims and shifting the movement towards implementing comparable worth through legislative action and collective bargaining. ${ }^{52}$ The major obstacle to judicial acceptance was the courts' reluctance to displace market rates and their fear that the project would pose too great an administrative burden on the judiciary in civil rights cases. The precise portion of the wage gap attributable to discriminatory devaluation was the subject of intense debate, ${ }^{53}$ with the regrettable result that the courts provided no Title VII remedy, even when the employer's own job-evaluation study indicated that women's wages were devalued. ${ }^{54}$

County E Municipal Employees v. Washington, 770 F.2d 1401, 1406-07 (9th Cir. 1985), which permitted employers to rely on market prices, even when the employer's own job-evaluation study indicated that women's jobs were undervalued. Together, the cases substantially closed off both the disparate treatment and disparate impact avenues of attack to sex-based wage discrimination resulting from occupational discrimination.

${ }^{52}$ By 1987, 20 states had made some comparable worth adjustments for state employees, but had not extended comparable worth to private employers. See Evans \& NELSON, sufra note 30, at 71-72. The history of the labor movement's involvement with comparable worth is traced in LINDA M. BLUM, BETWEEN FEMINISM AND LABOR: THE SigNIFICANCE OF THE COMPARABLE WORTH MOVEMENT 6-14 (1991) (explaining that, while the labor movement has historically had a poor record in representing working women, in recent years it has embraced comparable worth as part of its "new agenda").

${ }^{33}$ Most researchers admit that a significant portion of the male/female wage gap cannot be explained by human-capital factors such as differences in education, training, or experience. See CHARLES A. SULLIVAN ET AL., CASES AND MATERIALS ON EMPLOYMENT LAW 946 (1993). They disagree, however, as to what portion of the unexplained differential is attributable to discrimination. See id. Sociologists focusing on job-level rather than occupational segregation contend that as much as $75 \%$ of the gender wage gap is attributable to sex segregation. See Tomaskovic-Devey, supra note 49 , at 38 ('Job sex composition's contribution to the earnings pay gap is now estimated to be $75 \%$...."). Part of the problem is determining how to treat women's "preferences" for certain types of work. Most feminists are skeptical of preference arguments, arguing that women's apparent preferences are influenced by opportunity structures and workplace cultures. See Alice Kessler-Harris, Equal Employment Opportunity Commission v. Sears, Roebuck and Company: A Personal Account, 35 RADICAL HIST. REv. 57, 65-68 (1986) (arguing for a "multicausal" view of history which recognizes that women's preferences are not the only factor which shaped the role of women in the workforce); Vicki Schultz, Telling Stories About Women and Work: Judicial Interpretations of Sex Segregation in the Workplace in Title VI Cases Raising the Lack of Interest Argument, 103 HARV. L. REV. 1749, 1840 (1990) ("Courts who interpret sex segregation as women's own choice thus negate the very choice they purport to defend."). Even after adjusting for female preferences, however, one model concluded that implementing comparable worth would result in wage increases on the order of approximately $10 \%$. See MARK ALDRICH \& ROBERT BUCHELE, THE ECONOMICS OF COMPARABLE WORTH 124-27 (1986).

${ }^{54}$ See American Fed'n of State, County E' Mun. Employees, 770 F.2d at 1407 ("Though the comparability of wage rates in dissimilar jobs may be relevant to a determination of 
The basic insights of comparable worth theory, however, continue to have a particular salience for tort law. Comparable worth theory not only cautions that women's wages may not always be a fair measure of the value of women's activities in the workplace; but it also alerts us to the possibility of devaluation of women's activities in other areas, particularly in the home or other nonmarket settings.

\section{Devaluation of Potential}

The third example of race-linked and gender-linked devaluation comes from my own research in tort law. ${ }^{55}$ It involves how the law measures the potential of female and minority plaintiffs; specifically, the calculation of their loss of future earning capacity. Evaluating the potential of a human being is at once a speculative and important process. Particularly in cases in which plaintiffs are injured or killed when they are young, little reliable information may be available to predict how much they would have earned during their lifetime. ${ }^{56}$ This speculation about potential earning power is critically important on both a practical and a symbolic level. Loss of future earning capacity is a "big ticket" item of damages, which can make the difference between a modest and a sizable award. ${ }^{57}$ Because it is a measure of human potential, moreover, the price the law attaches to lost earning capacity tells us something about societal judgments concerning worth, specifically the worth of the individual plaintiff and the groups to which the individual belongs. It is an important way by which the law measures "promise," particularly the promise of our children.

While serving on the Iowa task force examining gender and race bias in the courts, ${ }^{58}$ I learned from judges and practitioners that it is commonplace in tort litigation to use gender-based, and sometimes also race-based, tables to determine two important components that go into calculating loss of future earning capacity-the work-life expectancy of the plaintiff and the average wage the plaintiff likely would have earned in the future. Briefly stated, loss of future earning

discriminatory animus, job evaluation studies and comparable worth statistics alone are insufficient to establish the requisite inference of discriminatory motive critical to the disparate treatment theory.").

${ }_{55}$ See Chamallas, supra note 15 , at $81-84$.

${ }^{56}$ See id. at $82-83$ (discussing the difficulties in evaluating the potential future earnings of children).

${ }^{57}$ See id. at 75 .

${ }^{53}$ The task force's findings and conclusions on civil damages are found in EQUALITY IN THE COURTS TASK FORCE, STATE OF IOWA, FINAL REPORT 113-22 (1993). 
capacity is typically measured by estimating the number of years the plaintiff would have worked had she not been injured (work-life expectancy) and the amount the plaintiff would have earned each year, reduced to present value. ${ }^{59}$

My research showed how estimates of each of these two significant components are often infected by race and gender bias-bias that is hidden from view by statistics. Thus, the estimates of work-life expectancy of women of all races and minority men are consistently lower than estimates for white men. This is because work-life expectancy is distinct from life expectancy. Work-life expectancy is a statistical measure derived from the past working experience of all people in a plaintiff's gender and racial group. It incorporates rates of unemployment, both voluntary and involuntary, as well as expected retirement age. ${ }^{60}$ Because women in the past stayed out of the workplace to raise children, women have a lower work-life expectancy than men, despite the fact that women generally live longer than men. ${ }^{61}$ Because of higher rates of unemployment and of incarceration, minority men also have a lower work-life expectancy than white men. ${ }^{62}$ Thus, based on data from the U.S. Bureau of Labor Statistics, the work-life expectancy for a white man injured at the age of thirty was estimated to be 4.7 years more than that of a minority man, 8.7 years more than that of a white woman, and 9.2 years more than that of a minority woman. ${ }^{63}$ Embedded within the seemingly neutral concept of "worklife expectancy" is thus the history of unequal treatment of female and minority workers, including the exclusion of married women from employment and the relegation of minority men to sporadic employment with little job security.

59 See 2 MARILYN MINZER ET AL., DAMAGES IN TORT ACTIONS $\S 10.22(3)$, at 10-64 to $10-90$ (1997) (emphasizing that the reduction in the victim's capacity to earn rather than the victim's actual earnings is what courts measure); Chamallas, supra note 15, at 79-81 (discussing standard formulations for calculating loss of earning capacity); Evelyn Esther Zabel, Note, A Plain English Approach to Loss of Future Eaming Capacity, 24 WASHBURN L.J. 253, 257-61 (1985) (demonstrating how to calculate loss of future eaming capacity).

co See Dale Funderburk, Worklife Tables: Are They Reliable?, TRIAI, Feb. 1986, at 44, 44-45 (discussing problems that arise in using standardized work patterns in statistical analysis).

${ }^{61}$ See 9 Paul M. Deutsch \& Frederick A. RafFa, Damages in Tort actions $\S 110.13$ tbls.7b.2 \& 7b.5 (1997).

${ }^{62}$ See id. $\$ 110.13$ tbl.7b.2.

${ }^{69}$ See id. $\$ 110.13$ tbls.7b.2 \& 7b.5; see also Funderburk, supra note 60, at $44-45$ (using 1977 data to find that work-life expectancy for women is 27.5 years, compared with 37.9 years for men). 
Gender and race bias also affects the calculation of average wages. When a plaintiff has no individualized track record of earnings, economists acting as expert witnesses frequently resort to genderbased and race-based tables of earnings to estimate future earnings. ${ }^{64}$ Because of wage discrimination and occupational segregation, predictions of future earnings for women and minorities are considerably lower than for white men, even when controlled for such factors as educational attainment. Thus, the projected lifetime earnings, discounted to 1990 present value, of a female college graduate have been estimated to be only sixty-five percent of those of a similarly situated male college graduate. ${ }^{65}$ The use of statistics in this context means that current race and gender disparities in wages will be projected into the future, and that bias in the setting of wages will continue to influence personal injury and wrongful death awards.

In one respect, the use of gender- and race-based tables to determine future earning capacity is an example of ordinary disparate treatment. Consider the case of twins-a boy and a girl-who are simultaneously severely injured in a car accident when they are children. Under prevailing doctrine, the boy would be entitled to a considerably higher recovery for loss of future earning capacity, solely because of his gender. This is a classic case of disparate treatment of similarly situated individuals, although few courts have found the practice unlawful. ${ }^{66}$

The use of gender- and race-based statistics is also, I believe, a stark example of gender- and race-linked devaluation. Deep-seated judgments about the importance of gender and race differences lie beneath the use of the statistical disparities. In projecting future

${ }^{64}$ See Chamallas, supra note 15 , at $81-83$ (discussing the assumptions made regarding work, gender, and race).

${ }^{65}$ See Interview with Richard Stevenson, Professor, College of Business Administration, University of Iowa, in Iowa City, Iowa (Aug. 25, 1993).

${ }^{66}$ In the United States, only two recent cases have questioned the propriety of using gender- or race-based data as a matter of common law policy. See Wheeler TarpehDoe v. United States, 771 F. Supp. 427, $455-56$ (D.D.C. 1991) (" $[I] \mathrm{t}$ would be inappropriate to incorporate current discrimination resulting in wage differences between the sexes or races or the potential for any future such discrimination into a calculation for damages resulting from lost wages."), rev'd on other grounds, 28 F.3d 120 (D.C. Cir. 1994); Reilly v. United States, 665 F. Supp. 976, $995-97$ (D.R.I. 1987) (calling defendant's suggested $40 \%$ reduction of plaintiff's expected working life "disparate treatment"), modified, 863 F.2d 149, 167 (1st Cir. 1988) (finding no clear error in the court's refusal to accept defendant's gender-specific work statistics). I have argued that the use of explicit race- or gender-based tables is unconstitutional. See Chamallas, supra note 15, at 104-24. 
earning capacity, only a few characteristics of the plaintiff are routinely used as guides to predict the future-notably, age, sex, and race. To some extent, it seems reasonable to rely on these factors to calculate future earnings. A person's age does affect how long he or she will likely be able to earn money and remain in the workforce. In our society, moreover, race and gender do matter: Being a woman or being an African-American does dampen one's earning prospects. However, what is not often noticed is that many other variables, such as religion, ethnicity, and marital status, also have predictive power, yet are not used to predict earning potential. The use of race- and gender-based data is thus highly selective. ${ }^{67}$ And it is this selectivity through which the process of devaluation takes place. The judgment to focus on race and gender-but not other personal traits-amounts to a judgment that race and gender tell us more about what a person will become, more about what a person is likely to achieve, than other traits that have been correlated in the past with the acquisition of wealth. Put another way, the categories of race and gender are thought to be particularly salient, highly plausible predictors of future earning capacity.

In the celebrated case City of Los Angeles $v$. Manhart, ${ }^{68}$ which challenged a gender-based pension benefit scheme under Title VII, Justice Stevens remarked on the selectivity of an employer's decision to exact higher contributions to the pension fund from women workers. Stevens argued that even though it was true that, on average, women lived longer than men, the same could also be said for married men versus single men. Yet the employer did not require married men to make higher contributions. ${ }^{69}$ Nor did the employer base contributions on the worker's ethnicity or race, despite the documented difference in mortality rates for these groups. ${ }^{70}$ Instead, the employer singled out gender for special treatment, to the disadvantage of fe-

${ }^{67}$ A similar observation about the underinclusiveness of using sex-segregated actuarial tables to predict life expectancy when such variables as race and residence also have predictive power was made in Lea Brilmayer et al., Sex Discrimination in EmployerSponsored Insurance Plans: A Legal and Demographic Analysis, 47 U. CHI. L. REV. 505, 511-13 (1980).

${ }^{6 s} 435$ U.S. 702 (1978).

${ }^{69}$ See id. at 710 n.18 (noting that married men tended to live 10 years longer than unmarried men).

${ }^{70}$ See id. at $709 \mathrm{n} .15$ (noting that life expectancy of blacks was 6.3 years shorter than whites). 
male employees. ${ }^{71}$ Justice Stevens noted that in this context, employers were probably deterred from using race as a variable because it was understood that the primary aim of Title VII was to make race irrelevant in employment decisions and, thus, it would have seemed unreasonable to base an employee's take-home pay on race. ${ }^{72}$

A clue as to why economists and others might tend to select both gender and race (but not other variables) when making predictions about future income comes from social cognition theorists who have examined biases in causal attribution. Causal attribution is a process by which people connect cause and effect, or assign certain causes to certain outcomes. In disciplines outside the law, there is a growing appreciation that " $[c]$ ausality is more than a scientific inquiry into the state of the world.... [and] that people's perceptions and descriptions of cause-and-effect relationships vary according to their time, place, culture, and interest. ${ }^{73}$ Historian Arthur McEvoy, for example, has sought to distinguish the causal attribution process from quasiscientific notions of objective causation, arguing that "[h]owever passionately people may believe that their customary patterns of causal attribution are 'objective' and 'natural,' those patterns are, inescapably, historical artifacts." 74

The causal attribution process is important in gaining an understanding of when we are inclined to blame the victim for her misfortune, rather than to ascribe the outcome to some factor beyond the victim's control. Reviewing the psychological studies, Linda Krieger explains how the content of group stereotypes affects causal attribution. ${ }^{75}$ The empirical evidence indicates that in making causal judgments, people often ascribe the cause of an action either internally (to the actor herself) or externally (to forces outside the actor) ${ }^{76}$

"See id. at 711. The employer in Manhart also used gender as a variable selectively. With respect to death benefits, it funded the program by equal contributions from male and female employees, declining to give women the benefit of their longer life span. See id. at 709 n.19. This one-way-street approach resembled the historical practice of insurers charging blacks more for life insurance, but not less for disability insurance. See id. at 709 n.16.

${ }^{72}$ See id. at 709.

${ }^{73}$ ARTHUR F. MCEVOY, THE TRIANGLE SHIRTWAIST FAGTORY FIRE OF 1911: SOCIAL CHANGE, INDUSTRIAL ACCIDENTS, AND THE EVOLUTION OF COMMON-SENSE CAUSALITY 2 (American Bar Found. Working Paper Series No. 9315, 1994).

${ }^{74}$ Id. at $2-3$.

${ }^{75}$ See Linda Hamilton Krieger, The Content of Our Categories: A Cognitive Bias Approach to Discrimination and Equal Employment Opportunity, 47 STAN. L. REV. 1161, 1204 07 (1995).

${ }^{76}$ See id. at 1204. 
There is a tendency, moreover, to attribute one's own behavior to external causes or situational factors. ${ }^{77}$ When evaluating another's action, however, one is more likely to attribute it to dispositional factors, such as the actor's personality, attitudes, or abilities. ${ }^{78}$ We are thus more likely to blame the victim when we are not the victim.

This situational/dispositional dichotomy also operates with respect to evaluating groups. Krieger explains that when an actor's behavior appears to confirm a stereotype about the actor's group, we attribute that behavior to a dispositional factor within the control of the actor. $^{79}$ If the behavior is inconsistent with our stereotype of the group, we are apt to seek out an external explanation and attribute the behavior to situational factors. ${ }^{80}$ Thus, for example, if a black student misses class, a white professor might unconsciously attribute the absence to the black student's lack of commitment or to her irresponsibility, in conformity with the professor's negative stereotypes about blacks. When an older, white, male student misses class, however, the same professor might assume that something special has happened, perhaps a car accident or sickness, that prevented the student from making it to class on that particular day. It is important to recognize that the process by which we make such causal judgments may take place instantaneously and unconsciously. The white professor may not realize that her judgment was infected by racial bias.

There is a relationship, I believe, between the factors that are assumed to be good predictors of the future and the situational/dispositional dichotomy. If the cause of an action is thought to stem from a person's disposition, then it makes "sense" to predict that the same behavior will occur in the future. In the prior example, the professor might rationally predict that the "irresponsible" black student will miss class again. When the cause is thought to be a product of the situation, however, it makes sense to assume that the same behavior likely will not occur unless the situation persists. Thus, the professor in our example might reasonably predict that the white student will probably make it to class the next day, unless there is another car accident or sickness. Through this process, stereotypes about a group not only distort present perceptions about behavior but also prejudice our judgments about the future. These distortions

\footnotetext{
$\pi$ See id. at 1205.

${ }^{78}$ See id.

${ }^{79}$ See id.

Bo See id.
} 
may occur although the person making the judgment sincerely believes that she is making a rational prediction.

With respect to future earning capacity, the judgment to select race and gender over other possible predictors may well be tainted by cognitive bias. Thus, I suspect that even if the data clearly indicated that, for example, Catholics on the average have higher incomes than Baptists, ${ }^{81}$ judges and jurors would be loath to predict future earning capacity based on religious denomination. The same could be said for ethnicity. I doubt that, in a wrongful death case of a JapaneseAmerican child, a court would permit an expert witness to testify that Japanese-Americans have higher incomes than the average college graduate. ${ }^{82}$ Finally, I would be surprised if the marital status of a single man was used against him in predicting his future income.

In each of these three examples, there would be a sense that using the variable of religion, ethnicity, or marital status was somehow inappropriate, perhaps even offensive, despite its predictive value. It is likely that judges and jurors would resist using these factors as a guide to the future, even if they were helpful in explaining historical patterns of income disparity. The social cognition studies lead me to believe that we are more likely to regard disparities correlated with religion, marital status, and, in some cases, ethnicity, as traceable to situational rather than dispositional causes. Thus, in the 1990s, it would seem unreasonable to ascribe a person's high earning power simply to the fact that she is a Catholic. Instead, any disparity between Catholics and Baptists is more likely to be explained in terms of

${ }^{81}$ This may well be the case. To investigate this hypothesis, my research assistant and I used data from the General Social Surveys, a computerized database containing large, nationally representative samples of individuals surveyed annually by the University of Michigan's Survey Research Center. For the most current years available (1991, 1992, and 1994), we found that Catholics were almost one and one-half times more likely than Baptists to have a household income of more than $\$ 25,000$. Our findings were based on a series of multiple regression equations which controlled for sex, age, race, education, marital status, and work income. This preliminary study suggests that religion is quite possibly a good predictor of income. See M. Douglas Scott, Analysis Prepared for Professor Martha E. Chamallas (Sept. 1997) (unpublished report, on file with author).

${ }^{82}$ The example is plausible; the median per capita income for Japanese-Americans in 1989 was $\$ 19,373$, compared to $\$ 14,056$ for all Americans. The median family income for Japanese-Americans was $\$ 51,550$, compared to $\$ 34,213$ for all Americans. See BuREAU OF THE CENSUS, U.S. DEP'T OF COMMERCE, 1990 CENSUS OF POPULATION, ASIANS AND PACIFIC ISLANDERS IN THE UNITED STATES 151 (1990) (summarizing data for Japanese-Americans); BUREAU OF THE CENSUS, U.S. DEP'T OF COMMERCE, STATISTICAL ABSTRACT OF THE UNITED STATES 469, 471 (1996) (summarizing data for all Americans). 
opportunities that were historically disproportionately available to Catholics. We are more apt to believe that, as opportunity structures change, the disparity between Catholics and Baptists will disappear, and, thus, that religion is not a valid predictor of the future. It might also seem unfair to saddle Baptists with the legacy of a past that had little to do with the personal traits of Baptists as a people. When we attribute the status of a group to external causes, we may be more willing to anticipate a change in status, particularly if we believe that America is not a rigidly stratified society and that there is a great deal of class mobility.

Similarly, willingness to believe that race and gender are reliable indicators of future earning capacity relates to causal attribution. If women's low earning potential is thought to stem from women's "natural" disposition to stay out of the workplace and care for the house and children, this "trait" will also likely prevent women from earning money in the future. Implicit in this judgment is the belief that women are the cause of their own low incomes and that it is not unfair to predict that this pattern will persist, given the nature of women. Likewise, the use of race to predict future earnings signals a willingness to ascribe the low incomes of African-Americans to internal factors, such as lack of motivation, lack of initiative, and lack of intelligence. ${ }^{83}$ Such a focus on dispositional factors can conveniently explain why the racial income gap will persist in the future, in spite of the formal legal commitment to equal opportunity. If this is the case, then negative stereotypes can become self-fulfilling prophecies as predictions about future potential translate into lower damage awards. In this way, causal attribution might, over time, transform into "objective" causation. ${ }^{84}$

${ }^{83}$ For an analysis of similar assumptions underlying the motivations and interests of women and minority workers in Title VII suits challenging patterns of gender and race segregation and hierarchy, see Schultz, supra note 53, at 1750 (discussing assumptions about women's job preferences that underlie judicial interpretation in Title VII cases); Vicki Schultz \& Stephen Petterson, Race, Gender, Work, and Choice: An Empirical Siudy of the Lack of Interest Defense in Title VII Cases Challenging Job Segregation, 59 U. CHI. L. REV. 1073, 1180-81 (1992) (noting the incorporation of race and gender stereotypes into Title VII jurisprudence).

${ }^{84}$ Historians also have begun to assess the importance of causal attribution to explain changes in popular thought about such phenomena as industrial accidents. Prior to the late 19th century, judgments about responsibility for an accident focused almost exclusively on the individual victim's behavior and events directly leading up to the accident. A shift occurred when people began thinking in terms of longer chains of causation and attributing responsibility to owners of factories, railroads, and other enterprises for failing to maintain safe premises and safe procedures. The shift in 
In years past, lawyers and judges openly accepted the view that damage awards for young female plaintiffs should be lower than for male plaintiffs, simply because it was presumed that a woman would marry, leave the workforce, and earn comparatively little in her lifetime. The value of a woman's potential was quite literally discounted by these commonplace projections, while no such discount was exacted from men who followed the same life path. ${ }^{85}$ Additionally, juries instructed to take the race of a child into account in determining a wrongful death award were given license to discount the potential of African-American children, reflecting the commonly held view that they would earn less in our racially stratified society. ${ }^{86}$

These highly contested cultural assumptions currently are camouflaged by the use of statistics. Courts routinely rely on gender-based tables, with little debate about whether it is fair to presume that women will interrupt their careers for a substantial period of time to raise children or whether the gender gap in wages will continue into the indefinite future. Although race-based generalizations are considered anathema in other areas of the law, ${ }^{87}$ they continue to distort judgments about human potential when they take the form of statistics based on past group-based experience. The past is uncritically

causal attribution changed the "common sense" of the matter and prompted an increase in lawsuits by injured patrons, even in the absence of significant changes in technology. See RANDOLPH E. BERGSTROM, CourTing DANGER: INJURY AND LAW IN NEW YORK CITY, 1870-1910, at 168-69 (1992) (attributing the increase in litigation in New York City between 1870 and 1910 to the public acceptance of more attenuated chains of causation); McEvoy, supra note 73, at 9 (positing that a famous 1911 industrial accident, the Triangle Shirtwaist Factory Fire, increased the public's willingness to attribute fault to employers rather than employees).

${ }_{85}$ See, e.g., Caron v. United States, 410 F. Supp. 378, 398 (D.R.I. 1975) (using shorter work-life expectancy and the discrepancy between male and female wages to discount a female plaintiff's future earning capacity), affd, 548 F.2d 366 (1st Cir. 1976); Frankel v. United States, 321 F. Supp. 1331, 1337-38 (E.D. Pa. 1970) (using likelihood of marriage as a factor in discounting future earning capacity of a female plaintiff), affd sub nom. Frankel v. Heym, 466 F.2d 1226 (3d Cir. 1972); see also Chamallas, supra note 15, at $90-95$ (discussing these cases).

${ }^{86}$ See, e.g., Powell v. Parker, 303 S.E.2d 225, 228 (N.C. Ct. App. 1983) (admitting expert testimony which used race as a factor in computing the projected income of a decedent in a wrongful death case).

${ }^{87}$ Under equal protection standards, explicit race-based classifications are subjected to the highest level of scrutiny, such that very few survive constitutional challenge. See Adarand Constructors, Inc. v. Pena, 515 U.S. 200, 235 (1995) (holding that strict scrutiny review should be applied to all racial classifications). As a matter of formal doctrine, there is no defense to a finding of explicit disparate treatment based on race under Title VII. The "bona fide occupational qualification" defense extends only to sex, national origin, and religion. See 42 U.S.C. $\$ 2000$ e-2(e)(1) (1994). 
accepted as a guide to the future, even though most people acknowledge that the past was hardly free of race and gender bias.

Most importantly, the selective use of statistics makes the process of evaluation appear neutral and rational. Hidden from view is the process by which we actively choose the factors we will use to predict the future. Lawyers know that the answer to a question often depends on how the question is framed. How we explain the past, particularly how we ascribe cause to effect, influences our predictions of the future. Implicit causal judgments that go to the heart of the enterprise of making predictions are themselves influenced by stereotypes. I interpret social cognition theory as teaching that predictions about the future are also active constructions of the future. Causal attribution can become material reality when perceptions are validated through legal institutions, as happens when a judge or jury places a dollar value on human potential. Cognitive bias distorts the interpretation of the past to make biased predictions of the future seem rational and fair. Devaluing the potential of women and minorities is thus accomplished in an updated, subtle form that looks more like economic expertise than race or gender bias.

\section{IMPLICIT HIERARCHIES OF VALUES IN THE LAW OF TORTS}

The three examples of devaluation discussed above suggest that the processes of devaluation vary somewhat from context to context. The judgment about the seriousness of a crime may be influenced by the race of the victim of the crime. The importance we ascribe to a particular type of job may depend on the gender of the prototypical worker in that job. We may gauge the potential of a plaintiff according to the past performance of others we deem to be "like" the plaintiff, focusing selectively only on factors that correspond to commonly held views about the causes of social inequality. In each example, however, race or gender-whether that of a crime victim, a majority of jobholders, or a statistical group-is noticed and affects judgments about relative worth. Devaluation operates at the cognitive level, influencing and shaping categories. However, devaluation also has material consequences because, particularly in the law, categorization crucially affects legal rights and liabilities.

In the past, critical scholars traced the devaluation process in specific tort doctrines. They focused, for example, on the exclusion of women's perspectives in the development of the "reasonable man" 
standard ${ }^{88}$ and teased out the gender, race, and class bias in the determination of what constitutes "outrageous" behavior. ${ }^{89}$ In this Article, I wish to synthesize some of this critical scholarship to develop a general theory about how the process of devaluation is accomplished in the law of torts.

I start with a structural observation about the value the law places on different types of injuries and types of damages. Although the standard texts do not always state so explicitly, there is little question that, in the contemporary law of torts, a higher value is placed on physical injury and property loss than on emotional and relational harm. ${ }^{90}$ This implicit hierarchy of value was even more apparent in an earlier era, when the scope of recovery in tort was more restricted and there were even fewer possibilities for recovering for marginal harms. Despite the liberalization of tort law, however, the basic hierarchy has remained intact. Over time, new rationales have emerged to justify privileging physical injury and property loss, coupled with new concerns about expanding tort liability to cover a wider scope of emotional or relational losses. More recently, moreover, it has become increasingly clear that an implicit hierarchy of types of damages has been constructed that complements the hierarchy of types of injury. The trend is toward favoring or privileging pecuniary or economic losses, such as lost wages or medical expenses, over nonpecuniary or noneconomic losses, such as pain and suffering, mental distress, lost companionship and society, loss of enjoyment of life, and punitive damages.

${ }^{8 s}$ See, e.g., Leslie Bender, A Lawyer's Primer on Feminist Theory and Tort, 38 J. LEGAL EDUC. 3, 20-25 (1988) (advocating incorporation of feminist principles and perspectives into the traditional "reasonable man" standard of care); Lucinda M. Finley, $A$ Break in the Silence: Including Women's Issues in a Torts Conerse, 1 YALE J.L. \& FEMINISM 41, $57-65$ (1989) (arguing that the "reasonable man" standard in tort law is suffused with a male perspective, to the exclusion of female perspectives).

${ }^{89}$ See Regina Austin, Employer Abuse, Worker Resistance, and the Tort of Intentional Infliction of Emotional Distress, 41 STAN. L. REV. 1, 4-5 (1988) (discussing the effect of race, gender, and class bias on employees' tort claims against their employers and advocating a more "worker-centric" theory of tort law).

${ }^{90} \mathrm{My}$ hierarchy of types of injuries does not include recovery in tort for pure economic loss. To be sure, restrictive doctrines also limit liability for economic loss, similar to the restrictions on recovery for mental distress. See KEETON ET AL., supra note 1, at 997-1002. However, because contract law provides considerable protection against economic loss, it would be inaccurate to describe this type of harm as marginalized in the law.

${ }^{91}$ Among the states, there is some variation in the classification of damages as economic or noneconomic. Economic loss clearly encompasses past and future wage loss, past and future medical expenses, and expenditures for custodial care. See, e.g., 


\section{A. Ranking Types of Injuries}

Until well into the twentieth century, the law purported to draw a sharp line between physical injury and property loss on the one hand, and mental distress and relational harm on the other. An 1861 English case, Lynch v. Knight, ${ }^{92}$ was often cited for the proposition that mental disturbance alone did not qualify as a legally cognizable harm. ${ }^{93}$ When plaintiffs recovered for pain and suffering or other mental distress associated with physical injuries, the courts were careful to explain that these damages were "parasitic" and that the cause of action was fundamentally based on physical injury. ${ }^{94}$ The ancient intentional torts of assault, false imprisonment, and offensive battery, which often compensated plaintiffs for nonphysical injury, were dismissed as exceptional cases. They provided protection against only the narrowest range of harms (e.g., loss of liberty, fear of imminent physical injury), and only to the extent necessary to assure that the injured party or his relatives would not seek revenge through violent retaliation.

The recognition of tort causes of action based principally on mental distress has been a slow and uneven process. ${ }^{96}$ The independent tort of intentional infliction of mental distress, free from any requirement of proof of physical injury, was first incorporated into the

Murphy v. Edmonds, 601 A.2d 102, 115-16 (Md. 1992). Noneconomic loss clearly encompasses pain and suffering, mental distress stemming from physical impairment or disfigurement, and loss of society, companionship, and affection of family members and other intimates. Because loss of consortium sometimes may also include the economic element of loss of domestic services, it can fit into both categories. See, e.g., Wolgang v. Mid-American Motorsports, Inc., 914 F. Supp. 434, 438-39 (D. Kan. 1996) (classifying loss of domestic services as an economic loss). There has also been some debate as to how loss of enjoyment of life should be categorized-whether the focus should be on the injured person's subjective reaction to his or her changed situation, or on the more objective valuation of the limitations on the person's life. See McDougald v. Garber, 536 N.E.2d 372, 375 (N.Y. 1989). Punitive damages do not easily fall into either category because they are designed to punish and deter, rather than to compensate for injury.

9211 Eng. Rep. 854 (H.L. 1861).

${ }^{93}$ See KEETON ET AL, supra note 1, at 55 \& n.3.

${ }^{9}$ See id. at 56-57 (stating that some independent tort, such as assault, would serve as the peg upon which courts hung mental-distress damages).

${ }_{95}$ See JOHN G. FLEMING, AN INTRODUCTION TO THE LAW OF TORTS 1-2 (2d ed. 1985)

("Tort liability ... provided a means whereby the victim of wanton aggression could be 'bribed' into abstaining from retaliation ...."); FOWLER V. HARPER ET AL., THE LAW OF TORTS $\$ 3.1$, at 266-68 (2d ed. 1986) (documenting the history of battery).

${ }_{96}$ The evolution of causes of action for emotional injuries is traced in Nancy Levit, Ethereal Torts, 61 GEO. WASH. L. REV. 136, 140-46 (1992). 
Restatement of Torts in $1948 .^{97}$ This "new tort," however, is not yet recognized in every state ${ }^{98}$ and is still approached cautiously by courts. The threshold requirements that the defendant's action must be "extreme and outrageous" and that the plaintiff's distress must be "severe" serve as significant limitations on recovery. In theory at least, the intentional infliction of the most trivial physical harm is a legal wrong. With respect to emotional harm, however, the law responds only to severe injuries and only if the wrongdoer is of the worst order and deliberately oversteps the bounds of common decency. ${ }^{99}$

Not surprisingly, the law is even more unlikely to permit recovery for negligent infliction of mental distress. Most jurisdictions have retained what is known as the "physical injury" or "physical manifestations" rule, which limits recovery to plaintiffs who can prove that their emotional trauma had physical consequences. ${ }^{100}$ The courts regard the physical injury requirement as a validation of the genuineness of the emotional harm, and allow the presence of the higher-ranked type of harm to lessen anxieties about expanding the boundaries of tort recovery. ${ }^{101}$

Another limiting doctrine that has substantially curbed tort recovery is the "bystander rule"-the doctrine prohibiting recovery by most persons who suffer trauma through witnessing the injury or

${ }^{97}$ See id. at 142.

${ }^{93}$ Pennsylvania, for example, has not yet explicitly recognized the tort. See Kazatsky v. King David Mem'l Park, Inc., 527 A.2d 988, 988-89 (Pa. 1987) (stating that recovery for intentional infliction of severe emotional distress by outrageous conduct had not been adopted by Pennsylvania courts); Small v. Juniata College, 682 A.2d 350, 355 (Pa. Super. Ct. 1996) (noting that at least one Pennsylvania court has held that the "tort of intentional infliction of emotional distress is not recognized in Pennsylvania"), appeal denied, 689 A.2d 235 (Pa. 1997). vides:

${ }^{99}$ The oft-cited comment to section 46 of the Restatement (Second) of Torts pro-

Liability has been found only where the conduct has been so outrageous in character, and so extreme in degree, as to go beyond all possible bounds of decency, and to be regarded as atrocious, and utterly intolerable in a civilized community. Generally, the case is one in which the recitation of the facts to an average member of the community would arouse his resentment against the actor, and lead him to exclaim, "Outrageous!"

RESTATEMENT (SECOND) OF TORTS $\$ 46 \mathrm{cmt}$. d (1965).

${ }^{100}$ Linda Kerber and I have traced the evolution of the restrictive rules limiting recovery for negligent infliction of mental distress. See Martha Chamallas with Linda K. Kerber, Women, Mothers, and the Law of Fright: A History, 88 MiCH. L. REV. 814, 819-23 (1990) (discussing judicial interpretations of the impact rule, the physical injury rule, and the bystander rule, and their consequences for recovery for fright-based injuries).

${ }^{101}$ See, e.g., Payton v. Abbott Labs, 437 N.E.2d 171, 178-81 (Mass. 1982); Reilly v. United States, 547 A.2d 894, 896-97 (R.I. 1988). 
death of their children, family members, or other persons. ${ }^{102}$ The courts still struggle with imposing restrictions beyond the general negligence requirement that some injury to the plaintiff be reasonably foreseeable. Some courts limit recovery to only those plaintiffs in the zone of physical danger. ${ }^{103}$ More liberal courts allow close family members outside the zone of danger to recover if they were present at the scene of the accident and suffered harm from a direct emotional impact. ${ }^{104}$ In this corner of the law, the liberalizing trend heralded by Dillon v. Legg, ${ }^{105}$ the famous 1968 California case, has apparently ended; even California has retreated from a flexible, case-by-case approach to a more rule-bound regime designed to limit the number of claims. ${ }^{106}$

Over time, the rationales for limiting claims of mental distress have shifted somewhat. Early cases tended to doubt the genuineness of mental distress claims. ${ }^{107}$ There were fears that plaintiffs could easily fake injuries and that it would be impossible to trace the invisible causal chain from the accident to the plaintiff's injury. ${ }^{108}$ The courts

${ }^{102}$ See Chamallas with Kerber, supra note 100, at 837-41, 851-58.

${ }^{103}$ See, e.g., Consolidated Rail Corp. v. Gottshall, 512 U.S. 532, 556 (1994) (adopting the zone-of-danger test for use in Federal Employers' Liability Act cases). In Consolidated Rail, Justice Thomas reported that the zone-of-danger test is used in 14 jurisdictions. See id. at 548.

${ }^{104}$ For a discussion of the variety of limitations placed on bystander recovery, see Dennis G. Bassi, Note, It's All Relative: A Graphical Reasoning Model for Liberalizing Recov ery for Negligent Infliction of Emotional Distress Beyond the Immediate Family, 30 VAL. U. L. REV. 913, 929-49 (1996) (reviewing the expansion of the bystander recovery rule and arguments for and against expansion).

${ }^{105} 441$ P.2d 912 (Cal. 1968). Dillon identified three factors that would serve as guidelines to determine whether an injury was "reasonably foreseeable" and, thus, compensable:

(1) Whether plaintiff was located near the scene of the accident as contrasted with one who was a distance away from it. (2) Whether the shock resulted from a direct emotional impact upon plaintiff from the sensory and contemporaneous observance of the accident, as contrasted with learning of the accident from others after its occurrence. (3) Whether plaintiff and the victim were closely related, as contrasted with an absence of any relationship or the presence of only a distant relationship.

Id. at 920 .

${ }^{106}$ See, e.g., Thing v. La Chusa, 771 P.2d 814, 829-30 (Cal. 1989) (replacing Dillon guidelines with more explicit preconditions for recovery).

${ }^{107}$ See Chamallas with Kerber, supra note 100, at 824-34 (tracing the rationale for denying recovery in the early cases).

${ }_{108}$ See, e.g., Bosley v. Andrews, 142 A.2d 263, 267 (Pa. 1958) (fearing a tremendous number of illusory, imaginative, or faked claims and denying recovery for fright unaccompanied by physical injury or physical impact), overruled by Niederman v. Brodsky, 261 A.2d 84, 86-87 (Pa. 1970). 
also often faulted the plaintiff for not being "tougher," suggesting that mental distress was more a function of the idiosyncrasies of the victim than of the dangerous quality of the defendant's actions. ${ }^{109}$ These concerns about proof still sometimes surface today, ${ }^{110}$ despite the wealth of medical knowledge describing and documenting various types of mental disturbances and widespread acknowledgment that there is no bright line between physical and mental injury."

In more recent decisions, however, the hesitation to award damages for mental distress is more often couched in terms of concerns about disproportionate liability for defendants and the lack of a clear stopping point for liability. For example, in a recent Supreme Court opinion, Consolidated Rail Corp. v. Gottshall, the Court held that the Federal Employers' Liability Act provided no redress for a worker who witnessed the negligent killing of a member of his crew, unless he met the strict "zone of danger" requirement. ${ }^{112}$ The facts of the case were appalling. The Conrail work-crew members, "most of them $\mathbf{5 0}$ to 60 years old and many of them overweight," ${ }^{\text {,13 }}$ were required to work virtually nonstop in ninety-seven degree weather. When one of the plaintiff's good friends on the crew collapsed, the plaintiff and other coworkers rushed to his side. They were ordered back to work by the crew supervisor. Five minutes later, the plaintiff's friend had a heart attack and died before the plaintiff's eyes. The supervisor "ordered the men back to work, within sight of [his] covered body."114

Despite these compelling facts, the Court concluded that a strict limit on liability was necessary, even though the factfinder in such a case would no doubt regard the plaintiff's distress as genuine and serious. ${ }^{115}$ The "more significant problem," in the majority's view (as written by Justice Clarence Thomas), was the prospect of imposing "nearly infinite liability" on defendants for genuine claims brought by

${ }^{109}$ See, e.g., Caputzal v. Lindsay Co., 222 A.2d 513, 517 (N.J. 1966) (concluding that a heart attack was an idiosyncratic reaction of plaintiff and ruling that there was no basis for recovery).

${ }^{110}$ See, e.g., Maloney v. Conroy, 545 A.2d 1059, 1061 (Conn. 1988) (denying recovery for emotional disturbance in a medical malpractice bystander case because of concerns about proof and fears of trivial and falsified claims).

${ }^{11}$ See Levit, supra note 96, at 186 ("While medical science persistently explores the interrelation of psychic and physiological states, law stubbornly resists the link.").

112 512 U.S. 532, 558 (1994).

113 Id. at 565 (Ginsburg, J., dissenting).

${ }^{114} I d$. at 536.

${ }^{115}$ See id. at 550-51 (rejecting the Third Circuit's test, which only required evidence of a likelihood of genuine and serious emotional injury). 
plaintiffs. ${ }^{116}$ Justice Thomas stressed that, unlike physical harm caused through impact, injuries produced through the mechanism of fear or other distress can occur far from the time and place of the original accident. ${ }^{117}$

Although I disagree strongly with the result in Gottshall, the administrative concern for line-drawing in mental distress cases is not groundless. In recent years, courts have been faced with new types of mental distress cases, in which, for example, plaintiffs seek recovery for their fear of contracting serious diseases such as AIDS or hepatitis. ${ }^{118}$ Plaintiffs now even sue for the trauma associated with causing injury, as when, for example, the driver of a car who accidentally runs over a child pedestrian sues for his or her own guilt and anguish at being the agent of death. ${ }^{119}$ Given the proliferation of new claims, courts cannot escape the necessity of drawing a line at some point. My argument is that they should determine that point with an awareness of the disparate impact of the rules they select.

The question is not whether the law will provide any compensation for genuine mental distress. Some legal protection already exists, and has existed for quite some time. When plaintiffs urge recognition of a new claim for emotional distress, they often stress that there is no comprehensive ban on recovery and highlight the illogic of incomplete coverage. ${ }^{120}$ Why, for example, will the law permit re-

${ }^{116}$ Id. at 552.

117 See id. at 545 ("Emotional injuries may occur far removed in time and space from the negligent conduct that triggered them."). The Court cited Richard N. Pearson, Liability to Bystanders for Negligently Inflicted Emotional Harm-A Comment on the Nature of Arbitrary Rules, 34 U. FLA. L. REv. 477, 507 (1982) for the observation that "[ $t$ ] he geographic risk of physical impact caused by the defendant's negligence in most cases is quite limited, which accordingly limits the number of people subjected to that risk. There is no similar finite range of risk for emotional harm." Gottshall, 512 U.S. at 545 n. 4 .

${ }^{118}$ See Karen L. Chadwick, Fear of AIDS: The Catalyst for Expanding Judicial Recognition of a Duty to Prevent Emotional Distress Beyond Traditional Bounds, 25 N.M. L. REv. 143, 143 (1995) (" $[T]$ he combination of fear and a deadly disease has led to a number of lawsuits where the fearful party has sought compensation for emotional distress; thus, the "AIDSphobia' cases were born.").

${ }^{119}$ See, e.g., Clomon v. Monroe City Sch. Bd., 572 So. 2d 571, 578 (La. 1990) (allowing recovery for emotional distress to motorist who struck and killed a child who was exiting a school bus); Guillory v. Arceneaux, 580 So. 2d 990, 997 (La. Ct. App. 1991) (permitting plaintiff motorist to recover damages for mental anguish resulting from her running over a pedestrian).

${ }^{120}$ Reviewing the evolution of the claim for negligent infliction of mental distress, Professor David Robertson has noted the logic in the "seemingly inexorable movement from liberalisation to further liberalisation" that plaintiffs often invoke. David W. Robertson, Liability in Negligence for Nervous Shock, 57 MOD. L. REV. 649, 654 (1994). 
covery for mental distress when a defendant acts intentionally, but not when the claim is for negligent infliction? ${ }^{121}$ Or why may relatives recover when a defendant mishandles a family member's corpse, ${ }^{122}$ but not when a defendant negligently kills a family member before their eyes? Concerns about fake injuries, the hypersensitive plaintiff, and tracing cause and effect are often no more difficult in these contested contexts than in those contexts in which recovery has already been permitted. ${ }^{123}$ Even those commentators who are loath to extend liability tend to recognize that these old arguments about problems of proving mental injury are now "regarded with some suspicion."

Rather, the crucial policy choices have to do with when to provide compensation, that is, in which contexts the genuine mental distress suffered by victims is so compelling that it deserves recognition in law. This complicated policy choice is hindered, rather than aided, by the existing hierarchy of types of injuries. There is no blanket guarantee that physical harm will be worse than emotional harm or that injury to property will create more suffering than injury to relationships, particularly when we realize that the severity of harm depends in part on the social situation of the victim. Indeed, the disabled child who loses the care and guidance of her only parent because of another's negligence may suffer a more grievous loss than the wealthy business owner whose building is destroyed. The need to draw the line somewhere gives no guidance as to the wisdom of the current limitations.

Under the surface of the administrative objections to extending liability for mental distress probably lies a more fundamental objection about the desirability of affording monetary compensation for

Robertson, however, argues for more caution, expressing concern about "the slippery slope" of increasing liability, especially difficulties in judicial administration. Id. at 655.

${ }^{121}$ See the plaintiff's arguments for recovery for negligent infliction of mental distress suffered by bystanders in Dillon v. Legg, 441 P.2d 912, 921 (Cal. 1968) (arguing that reasonable foreseeability is the norm for recovery in negligence claims, and that it is reasonably foreseeable that a mother will be in close proximity and will suffer emotional distress upon witnessing her child's accident).

${ }^{122}$ Recovery for negligent infliction of severe emotional distress in connection with the mishandling of a corpse has long been available in most jurisdictions. See, e.g., Gammon v. Osteopathic Hosp., Inc., 534 A.2d 1282, 1283 (Me. 1987) (permitting a cause of action for the negligent infliction of severe emotional distress after a son found a leg of his recently deceased father in a bag believed to contain his father's personal belongings).

${ }^{123}$ See Ira Mark Ellman \& Stephen D. Sugarman, Spousal Emotional Abuse as a Tort?, 55 MD. L. REV. 1268, 1298-1301 (1996) (acknowledging significant problems with traditional explanations for limiting recovery in emotional distress cases).

${ }^{124}$ Id. at 1299. 
emotional distress, even when it is clear that plaintiff's injuries are genuine, sufficiently serious to warrant legal attention, and properly attributable to the defendant's wrongful conduct. Many people recoil from reducing emotions and relationships to a dollar figure, and consider it degrading and perhaps even immoral to evaluate human life and human relationships according to commercial measures. ${ }^{125}$ The popular cynicism surrounding the tort system may in part reflect the belief that plaintiffs who seek large sums for intangible injuries are the least deserving, that their very willingness to exploit the system is a testament to the superficiality of their injury.

A standard response to this "money cannot buy love" argument against damages for emotional distress is that it is too late to complain about such a basic feature of the torts system, unless one is prepared to do away with large areas of tort liability. ${ }^{126}$ Few people would now question whether there ought to be a cause of action for the wrongful death of children, although many once hesitated to commodify the parent-child relationship by placing a monetary value on children's lives. ${ }^{127}$ Further, courts now generally agree that parents ought to be afforded some recovery in wrongful-birth claims, at least to offset the extraordinary expenses of raising a disabled child. ${ }^{128}$ The fear that tort judgments will stigmatize children and diminish the value of the parent-child relationship has generally given way in the face of the need for compensation and a sense that exonerating defendants in

${ }^{125}$ See Richard L. Abel, Torts, in THE Polrtics of LAW, supra note 17, at 326, 344 ("Nonpecuniary damages also dehumanize the response to misfortune, substituting money for compassion, arousing jealousy instead of sympathy, and treating experience and love as commodities.").

${ }^{126}$ See, e.g., Peter A. Bell, The Bell Tolls: Toward Full Tort Recovery for Psychic Injury, 36 U. FLA. L. REV. 333, 399-408 (1984) (arguing that similarities between the causes and symptoms of psychic injury and physical pain make it arbitrary to deny recovery for psychic harm).

${ }^{127}$ See Viviana A. Zelizer, Pricing the Priceless ChILd 113-37 (1985) (discussing the controversy surrounding insuring children's lives); $c f$. Steven P. Crowley \& Jon D. Hanson, The Nonpecuniary Costs of Accidents: Pain-and-Suffering Damages in Tort Law, 108 HARV. L. REV. 1785, 1906-14 (1995) (suggesting that society is willing to endorse tort compensation for pain and suffering even when it would seem undesirable to insure against such losses).

${ }^{123}$ See, e.g., Lininger v. Eisenbaum, 764 P.2d 1202, 1208 (Colo. 1988) (holding that in a wrongful-birth action, parents may recover at least extraordinary medical and educational expenses involved in raising their son); Greco v. United States, 893 P.2d 345,351 (Nev. 1995) (establishing the availability of damages for a parent's emotional distress and the extraordinary medical and custodial care expenses involved in raising a severely disabled child); Becker v. Schwartz, 386 N.E.2d 807, 813-14 (N.Y. 1978) (permitting the plaintiffs in a wrongful-birth suit to recover for pecuniary loss incurred in the care and treatment of a child until her death, but not for emotional injuries). 
such cases would be unjust. ${ }^{129}$ In short, the fact that money is inadequate compensation does not mean that denial of recovery is preferable. Money damages may be the best we can do.

The question of whether or not to provide money compensation for emotional harm poses a classic "dilemma of difference."130 If courts legally recognize such claims and award damages, they risk commodifying and depersonalizing emotions and relationships. ${ }^{131}$ This danger is of particular concern for feminists, because women have taken on the lion's share of the emotional work in our society and are more frequently the caretakers of children, elderly parents, and other dependent persons. ${ }^{132}$ The irony is that legal recognition of injury may serve to trivialize, or at least distort, women's suffering.

One eloquent critic of affording money damages for emotional and relational injuries, for example, has expressed the concern that such awards send the message that "[a]ll relationships have a monetary equivalent and hence can be bought and sold."13s The award of damages may further imply that it is appropriate to rank intimate relationships along "a single scale," based on the assumption "that an impaired partner will be discarded, like any other consumer product in our throwaway society." us to ignore the special, individualized qualities of relationships.

On the other hand, if we do not give adequate legal recognition to claims for emotional harm, women's suffering may become invisible, and the material hardships women face will certainly not be reduced by denying monetary relief. The dilemma arises because both strategies have the potential to backfire and harm the "different" group in the process.

Double binds or dilemmas of difference such as this have been described by philosopher Marilyn Frye as one of the "most character-

${ }^{129}$ See, e.g., Marciniak v. Lundborg, 450 N.W.2d 243, 246 (Wis. 1990) (stating that allowing parents to recover for wrongful birth will enhance rather than disparage the emotional well-being of the entire family).

${ }^{130}$ The theorist who coined the phrase "dilemma of difference" is Martha Minow. The fullest elaboration of Minow's analysis of this phenomenon is MARTHA MINOW, MAKING ALL THE DIFFERENCE: INCLUSION, EXCLUSION, AND AMERICAN LAW (1990).

${ }^{131}$ For a discussion of the dangers of commodification, see Margaret Jane Radin, Market-Inalienability, 100 HARV. L. REV. 1849, 1870-87 (1987) (discussing problems associated with commodification, such as alienation of human beings and loss of personal autonomy).

132 See infra text accompanying notes 185-86.

13s Abel, supra note 125, at 337 .

${ }^{134} I d$. 
istic and ubiquitous features of the world as experienced by oppressed people." ${ }^{\text {135 }}$ Given the social inequality of women in the marketplace and in larger society, it is hardly surprising that the policy choices offered in this area of tort law each carry potential hazards. The commodification dilemma posed with respect to damages for emotional distress is not intrinsic to tort law, but stems from women's marginal status in our culture.

When faced with dilemmas of difference, feminist scholars have tried to escape the horns of the dilemma by scrutinizing the terms underlying the basic choices. ${ }^{136}$ The way out of the dilemma of difference related to emotional distress claims is not to choose either commodification or legal nonrecognition, but to question whether and why legal recognition must result in commodification in the specific context. My hypothesis is that legal claims for emotional distress have been devalued in part because they are associated with female plaintiffs. In a less biased, more inclusive tort system, claims for damage to emotions and relationships would not be viewed either as property rights or commodities, on the one hand, or as lacking in value, on the other. Instead, in a specific context, the decision to recognize a right to compensation would depend more on whether the law wished to validate the damaged relationship or to acknowledge the reasonableness of a plaintiff's emotional response. If the balance was not so weighted against emotional harm in the first place, the Supreme Court's ruling in Gottshall, for example, might have turned on whether the law ought to encourage coworkers to care for and worry about each other's safety and health or whether it is reasonable for employees to be distressed when they are ordered to work around the corpse of a fellow worker. ${ }^{137}$

With respect to the classification of mental distress as a type of harm worthy of legal notice, the law has gradually moved from no recognition to partial recognition. Categorical denials of recovery

193 MARILYN FRYE, THE POLITICS OF REALITY: ESSAYS IN FEMINIST THEORY 2 (1983).

136 The feminist refusal to accept the terms of the dichotomy and instead to break the dichotomy by seeing the interconnectedness of seemingly opposite terms is well illustrated by the scholarship of Elizabeth Schneider. See generally Elizabeth M. Schneider, Feminism and the False Dichotomy of Victimization and Agency, 38 N.Y.L. SCH. L. REV. 387, 395 (1993) ("[V]ictimization and agency are not extremes in opposition: they are interrelated dimensions of women's experience."); Elizabeth M. Schneider, The Dialectic of Rights and Politics: Perspectives from the Women's Movement, 61 N.Y.U. L. REV. 589, 601-04 (1986) (explaining that feminist theory is rooted in a dialectical process in which "the 'private' and 'public' worlds are inextricably linked").

${ }^{137}$ See supra text accompanying notes 112-16. 
have been replaced by a welter of special, onerous requirements placed on recovery of this "nonprivileged" type of harm. It has not been a straight-line trend toward liberalization. Instead, the highwater mark for plaintiffs probably was reached in the 1970s, before the more conservative reaction in the 1980 s led to successive waves of tort reforms favoring defendants. ${ }^{138}$ The many doctrinal developments have not, however, dislodged the basic hierarchy. It is still much easier to recover for physical injury and property loss than for mental distress.

Like emotional harms, relational injuries continue to rank at the bottom of the legal hierarchy of injuries. At different historical periods, certain relational claims have gained visibility, but there has never been widespread legal protection for this type of injury. Many of the old intentional torts which sought to protect intimate and family relationships, such as criminal conversation, ${ }^{139}$ seduction, ${ }^{140}$ breach of a promise to marry, ${ }^{141}$ and alienation of affections, ${ }^{142}$ have either been abolished ${ }^{143}$ or have little impact in the law. Notably, there has been no development comparable to the emergence of the tort of intentional infliction of mental distress that provides general protection

${ }^{19 s}$ Developments in California are emblematic of the more general trend. The flexible, plaintiff-oriented approach to bystander recovery for mental distress in Dillon v. Legg, 441 P.2d 912 (Cal. 1968), was replaced by the more restrictive, rule-bound approach in Thing v. La Chusa, 771 P.2d 814 (Cal. 1989). For discussion of these holdings, see supra notes $104-06$ and accompanying text.

${ }^{139}$ See MARC A. FRANKLIN \& ROBERT L. RABIN, TORT LAW AND ALTERNATIVES 829 (6th ed. 1996) ("ITwenty] states have abolished the action entirely either legislatively or judicially."). For a recent decision rejecting the claim, see Neal v. Neal, 873 P.2d 871,874 (Idaho 1994) (noting the outdated rationale behind the tort of criminal conversation and abolishing it).

${ }^{140}$ See Jane E. Larson, "Women Understand So Little, They Call My Good Nature Deceit"': A Feminist Rethinking of Seduction, 93 COLUM. L. REv. 374, 401 (1993) (describing the "handful" of reported seduction cases brought since 1960); Lea VanderVelde, The Legal Ways of Seduction, 48 STAN. L. REV. 817, 867-68 (1996) (discussing the historical basis for the tort of seduction).

141 See Martha Chamallas, Consent, Equality, and the Legal Control of Sexual Conduct, $61 \mathrm{~S}$. CAL. L. REV. 777, 786-87, 830-35 (1988) (stating that suits brought for breach of promise to marry fell into disfavor in the early half of this century).

${ }^{142}$ See Hoye v. Hoye, 824 S.W.2d 422, 427 (Ky. 1992) (abolishing the tort of intentional interference with the marital relation because of its similarity to the alreadydiscredited action for alienation of affections).

${ }^{143}$ See Note, Heartbalm Statutes and Deceit Actions, 83 MICH. L. REV. 1770, 1770-71 (1985) (noting that many states have either enacted "heartbalm" statutes, abolishing these types of actions, or have passed laws limiting them). 
against intentional interference with important relationships. ${ }^{144} \mathrm{Al}$ though there has been some modest growth in the recognition of negligent infliction of relational injury, the law is still characterized by discrete, narrowly bounded causes of action.

The two most important contemporary legal bases for compensation for negligent interference with relationships-wrongful death and loss of consortium-did not exist in their current form at common law. Relatives had no common law right to recover for wrongful death of a family member. ${ }^{145}$ Claims arising from nonfatal injuries were limited to a husband's claim for loss of his wife's services, sex, and society, and a father's claim for loss of his child's services. Both claims were likened to a master's claim for deprivation of his servant's services and characterized as a material loss to the "owner." claims were also given only to the dominant party: A wife or child suffered no legally cognizable relational injury. ${ }^{147}$ The one-sided nature of these claims made it difficult to characterize them as relational injuries, at least insofar as relational harms rest on a recognition of in-

${ }^{141}$ Conceivably, claims for sexual and racial harassment in the workplace could be regarded as claims for intentional interference with plaintiff's employment relationship. Victims of harassment by coworkers and supervisors, however, most often bring claims for intentional infliction of mental distress, precisely because there is no other widely recognized tort cause of action for such relational harm. The tort of intentional interference with the employment relationship has traditionally been used by employers to prevent other employers from stealing away valuable employees or to prevent third parties from pressuring the employer to fire the plaintiff-employee. Recent cases have occasionally extended the claim to allow an employee to sue a supervisor who induces the employer to fire the employee. SeeSULLIVAN ET AL., supra note 53, at 829-41 (discussing recent case law involving claims for intentional interference with the employment relationship).

145 The English rule denying recovery was first enunciated in Baker v. Bolton, 170 Eng. Rep. 1033, 1033 (K.B. 1808) ("[T] he death of a human being could not be complained of as an injury; and in this case the damages, as to the plaintiff's wife, must stop with the period of her existence."). Partial recovery was first afforded to dependents of the deceased by Lord Campbell's Act (Fatal Accidents Act), 1846, 9 \& 10 Vict. ch. 93 (Eng.) (providing a cause of action for wrongful death). The developments in the United States are canvassed in Moragne v. States Marine Lines, Inc., 398 U.S. 375, $384-93$ (1970) (tracing the history of the treatment of wrongful death suits in the United States from the adoption of the English rule denying recovery, to the adoption of a wrongful death statute in all $\mathbf{5 0}$ states). Similar to the reservations expressed in extending recovery for purely mental distress claims, opponents of wrongful death actions expressed fears that allowing recovery would lead to "runaway damages" and that it was "immoral" to place a value on human life. See JOHN W. WADE ET AL., PROSSER, WADE AND SCHWARTZ'S CASES AND MATERIALS ON TORTS 449-550 (9th ed. 1994).

${ }^{146}$ See infra notes 236-37 and accompanying text.

${ }^{147}$ See Diaz v. Eli Lilly \& Co., 302 N.E.2d 555, 556-59 (Mass. 1973) (tracing the history of the spousal consortium claim). 
terdependency among persons, distinct from both individual property rights and emotional harm.

Under current negligence law, courts routinely allow claims for wrongful death ${ }^{148}$ and spousal consortium on a gender-neutral basis. ${ }^{149}$ In its updated form, the loss-of-spousal-consortium claim has lost its property-like character, especially because most states now hold that the primary accident victim, rather than the consortium claimant, has the right to recover for loss of household services. ${ }^{150}$ Nonetheless, it is still fair to say that recovery for relational injuries remains at the outer margins of the law.

In most states there is no cause of action for the loss of companionship and society of family members other than spouses. Consistent protection for loss of consortium of children, parents, grandparents, and siblings is notably lacking. ${ }^{151}$ Recovery virtually never extends beyond traditional relationships. ${ }^{152}$ Even legal commentators rarely debate the merits of affording compensation for relational injuries to the partners in same-sex or other nonmarital relationships, or for damage to life-long friendships. In life, the existence and quality of these intimate human relationships may well be essential to a person's happiness and well-being. Tort law, however, generally treats relational injuries merely as supplemental to "primary" claims for physical harm, serving principally to increase the total recovery for the family unit.

143 The scope of the wrongful death claim depends on the particulars of the specific state statute authorizing recovery. See MALONE, supra note 1, at 2944 (discussing pecuniary and nonpecuniary elements of damages).

149 See FRANKLIN \& RABIN, supra note 139, at 250 (noting that "virtually all states have come to recognize the loss of consortium action for both spouses"). Utah is an exception to the near-universal recognition of loss of spousal consortium. See Hackford v. Utah Power \& Light Co., 740 P.2d 1281, 1286-87 (Utah 1987) (rejecting cause of action).

${ }^{150}$ See DAN B. DOBBS, LAW OF REMEDIES $\$ 8.1(5)$, at 660 (2d ed. 1993) (stating that today, only the injured spouse should recover for loss of services because each spouse has the right to his or her own efforts and the products of those efforts).

${ }^{151}$ Dan Dobbs reports that approximately a dozen states allow children to sue for the loss of parental consortium. When a child is injured, the parents' claim is generally limited to recovery for loss of services; only a few states allow the parents to recover for loss of society and companionship when the child survives. See DAN B. DOBBS, TORTS AND COMPENSATION 437-38 (2d ed. 1993). Louisiana may be the only state to permit grandparents and siblings to recover for loss of consortium. However, their claims are recognized only if the person suffering physical injury has no surviving spouse, children, or parents. See LA. Crv. CODE ANN. art. 2315 (West 1997).

${ }^{152}$ See Elden v. Sheldon, 758 P.2d 582, 588 (Cal. 1988) (en banc) (denying loss-ofconsortium recovery to unmarried cohabitants). 
The hierarchy of types of injuries is perhaps most evident in the typical law school curriculum, particularly if we focus on what is left out as well as what is covered in the classroom. My impression is that most first-year torts courses focus almost exclusively on the "privileged" types of injury, omitting extensive discussion of such topics as wrongful death, loss of consortium, and negligent infliction of mental distress. ${ }^{153}$ The message is that "real" injuries involve physical harm and loss of property and that we should be more skeptical about the legitimacy or worth of claims of emotional loss or relational injury.

\section{B. Ranking Types of Damages}

The implicit hierarchy of types of damages, which ranks pecuniary over nonpecuniary damages, is of more recent origin than the hierarchy of injuries. At first blush, this hierarchy may appear to duplicate the hierarchy of types of injuries in that both privilege tangible over intangible harms. However, it is important to note at the outset that many types of injuries give rise to both pecuniary and nonpecuniary damages. Thus, for example, plaintiffs who suffer physical injury not only seek recovery for pecuniary damages consisting of medical expenses, wage loss, and loss of future earning capacity, but also for nonpecuniary damages for pain and suffering and loss of enjoyment of life. A plaintiff suing for negligent infliction of mental distress is likely also to have medical expenses and loss of income; a wrongful death beneficiary may recover for loss of pecuniary support and maintenance as part of the relational injury. ${ }^{154}$ The hierarchy of damages thus operates within the categories of types of harm to give higher priority to the pecuniary or economic aspects of the damage claim.

The implicit hierarchy of damages is most evident in statutory proposals for tort reform and judicial pronouncements rejecting challenges to reform measures. Beginning with the movement for workers' compensation, tort reform has most often targeted nonpecuniary

${ }^{153}$ Particularly now that many law schools have reduced torts from a six-credit, fullyear course to a three- or four-credit, one-semester course, the pressure to cut down on coverage is intense. The excellent casebook I currently use devotes only 31 pages to negligent infliction of emotional distress, with only "note" treatment of loss of consortium. See FrankLIN \& RABIN, supra note 139, at 226-57.

${ }^{154}$ Claims for loss of property, however, will only rarely include a mental distress element of damages. Once shorn of the services element, loss-of-consortium claims may also consist entirely of nonpecuniary losses. 
damages, suggesting that these damages are somehow less essential to a fair system of compensation than damages for economic loss. ${ }^{155}$ To be sure, workers' compensation and automobile no-fault schemes were not designed to disfavor plaintiffs: the quid pro quo for giving up noneconomic loss was a quicker recovery for plaintiffs who were no longer saddled with the difficult task of proving negligence. Nevertheless, these insurance systems reflected a choice to curtail recovery for nonpecuniary loss, and thus implicitly set a higher priority on recovery for pecuniary loss.

The two more recent waves of tort reforms-those spurred by the medical malpractice "crisis" of the 1970s and the litigation explosion of the 1980s-clearly follow the damages hierarchy. Together, they provided the political impetus for a variety of statutory caps on noneconomic damages, particularly in actions against health care providers. By 1990, some kind of cap or limit had been enacted in well over half of the states, some extending to all personal injury suits. ${ }^{156}$ Most recently, there has been growing support for federal legislation that would force all the states to cap noneconomic losses in health-care-liability actions. ${ }^{157}$

This sharp curtailment on noneconomic damages, particularly without the quid pro quo found in earlier reforms, has prompted constitutional challenges based on various grounds, including the rights to jury trial, equal protection, due process, and access to the courts. So far, the results are mixed, with no clear determination of the legality of caps. ${ }^{158}$ However, the debate has provided an occasion for some courts to validate the legislative priorities and express a clear preference for economic damages over noneconomic damages. Thus, in upholding a statutory cap, the California Supreme Court voiced its approval of the position taken in an $\mathrm{ABA}$ report on medical malpractice which flatly declared that "the first priority of the tort system is to compensate the injured party for the economic loss he has suffered." $m$ It further impugned the status of noneconomic

155 See Lucinda M. Finley, Female Trouble: The Implications of Tort Reform for Women, 64 TENN. L. REv. 847, 850 (1997) ("Nonpecuniary loss damages have been a favorite target of tort reformers, singled out as a seemingly easy mark.").

${ }_{156}$ See DOBBS, supra note 151 , at 792-93.

${ }^{157}$ See infra notes $219-27$.

158 See DOBBS, supra note $150, \S 8.8$, at $686-87$ (noting that it is easier to sustain constitutional challenge if the cap targets only noneconomic damage).

159 Fein v. Permanente Med. Group, 695 P.2d 665, 681 n.17 (Cal. 1985) (quoting Lyman M. Tondel, Jr., Medical Professional Liability, 102 A.B.A. REP. 849 (1979)). The 
damages by asserting that, despite being well-established in the law, noneconomic damages were suspect. Citing legal commentators and a dissenting opinion by Justice Traynor, ${ }^{160}$ the court stated:

Thoughtful jurists and legal scholars have for some time raised serious questions as to the wisdom of awarding damages for pain and suffering in any negligence case, noting, inter alia, the inherent difficulties in placing a monetary value on such losses, the fact that money damages are at best only imperfect compensation for such intangible injuries and that such damages are generally passed on to, and borne by, innocent consumers. ${ }^{161}$

The New York Court of Appeals expressed similar sentiments when it held that there could be no recovery for loss of enjoyment of life unless the plaintiff had "some cognitive awareness." the court downgraded recovery for noneconomic loss by asserting that it "stands on less certain ground than does an award for pecuniary damages," and rests on the "legal fiction" that money damages can compensate for such harms as pain and suffering and loss of enjoyment of life. ${ }^{163}$

The judicial mistrust of noneconomic damages has been echoed by the torts establishment, particularly by those who approach torts from a "law and economics" bent. ${ }^{164}$ Their influence has been felt by

ABA report denounced caps on economic damages but took no position on the propriety of capping noneconomic losses. See Tondel, supra.

${ }^{16}$ See Seffert v. Los Angeles Transit Lines, 364 P.2d 337, $344-47$ (Cal. 1961) (Traynor, J., dissenting). Because Justice Traynor is most often credited with liberalizing recovery for plaintiffs, his position in Seffert might seem odd. However, in that case, he did not argue that recovery for pain and suffering should generally be scaled back, but simply that the plaintiff's award was excessive. He did characterize nonpecuniary awards as "increasingly anomalous" in a modern mechanized society in which losses are distributed through insurance and in which the costs of accidents are passed on to consumers through price increases. See id. at 345. Thus, Traynor's fondness for "enterprise liability" - most often connected to his willingness to impose strict liability on product manufacturers and other businesses-led him to distrust nonpecuniary damages as less susceptible to an insurance model of tort liability.

${ }^{161}$ Fein, 695 P.2d at 680-81. The commentators cited were Clarence Morris, Marcus L. Plant, Louis L. Jaffe, and William Zelermyer. Seeid. at 681.

${ }_{162}$ McDougald v. Garber, 536 N.E.2d 372, $374-75$ (N.Y. 1989).

${ }^{169} \mathrm{Id}$.

${ }^{164}$ The most common argument put forward by economics-minded scholars is the "optimal insurance" view. Proponents of this view argue that the value of pain and suffering should be measured by whether a person would have bargained for and paid for insurance against such a loss. The economists then reason that such a bargain would not be rational because money is worth less to a person in an injured state than it is to a healthy person. See 2 AMERICAN LAW INST., REPORTER'S STUDY, ENTERPRISE RESPONSIBILITY FOR PERSONAL INJURY 207 (1991) [hereinafter ENTERPRISE RESPONSIBILITY] ( ${ }^{a}[W]$ e have no reason to suppose that in their injured state they would actu- 
the American Law Institute, as evidenced by a 1991 report addressing awards for pain and suffering. ${ }^{165}$ The authors' commitment to the hierarchy of damages is most evident in the structure they selected to examine the issue. The report deals at length with the question of whether there should be any award for pain and suffering, discussing the possible abolition of noneconomic damages quite seriously. ${ }^{166} \mathrm{Al}$ though the authors fall short of recommending total abolition, ${ }^{167}$ they include no comparable discussion of the wisdom of expanding recovery for noneconomic damages. The report contains no treatment, for example, of whether the law fails to compensate for important noneconomic losses experienced by victims of negligence or other fault. What is presented as a balanced discussion of the issues is actually quite skewed. The wisdom of the hierarchy of damages is largely presumed, with the focus on the more limited question of how far the law should cut back on its traditional rules governing noneconomic loss. ${ }^{168}$

The latest academic skirmish over the propriety of noneconomic damages has generated a wider debate over the nature of compensation generally, particularly whether money damages are appropriate when an injury, such as the loss of society of a child, is not reducible to a monetary figure. ${ }^{169}$ These days, defendant-oriented commenta-

ally enjoy the money any more than they would while they were healthy."). These assumptions are challenged in Mark Geistfeld, Placing a Price on Pain and Suffering. $A$ Method for Helping Juries Determine Tort Damages for Nonmonetary Injuries, 83 CAL. L. REV. 775, 794-96 (1995) (noting that the pain-and-suffering injury may either increase, decrease, or not affect the individual's ability to derive satisfaction from money after the accident). Recently, law-and-economics scholars have also argued that consumers may in fact demand insurance against nonpecuniary losses. See Steven P. Croley \& Jon D. Hanson, The Nonpecuniary Costs of Accidents: Pain and Suffering Damages in Tort Law, 108 HARV. L. REV. 1785, 1835-45 (1995) (discussing "nonmarket" evidence of consumer demand for pain-and-suffering insurance). For a critique of the optimal insurance view, see Margaret Jane Radin, Compensation and Commensurability, 43 DUKE L.J. 56, 7580,77 (1993) (" $[1] t$ may be that people reject the idea of purchasing insurance because they reject the symbolism of the transaction.").

${ }^{165}$ See 2 ENTERPRISE RESPONSIBILITY, supra note 164.

166 See 2 id. at 204-17 (discussing the "uneasy case for pain and suffering").

${ }^{167}$ The study recommends that damages for pain and suffering be limited to those victims who suffer "significant injuries" and that juries should be provided with disability profiles which rank or scale injuries from the relatively moderate to the gravest. Dollar amounts would be attached to the profile to be used as guidelines for setting damage awards. See 2 id. at 230.

${ }^{168}$ See 2 id. at $204-30$ (discussing the rationale for excluding much of what is now compensable noneconomic loss).

${ }^{169}$ The debate has been cast as whether some values are "incommensurable" in the sense that they cannot be precisely measured by the same scale. Professor Cass Sunstein has stated that "[i]ncommensurability occurs when the relevant goods cannot be 
tors most often stress the imprecision of nonpecuniary awards and argue that they do not really serve the purpose of restoring plaintiffs to the position they were in before the accident. ${ }^{170}$ Those scholars less committed to downsizing tort judgments emphasize the expressive function of law. They stress that tort judgments are not only about money, even though the award of damages is the principal tort remedy. Instead, they argue, a judgment also functions as a way of demonstrating the importance we place on human relationships and on legal rights. These interests may deserve legal recognition, even though they may lack precise market valuation. ${ }^{17}$

Not surprisingly, the debate about nonpecuniary loss echoes many of the arguments and counterarguments surrounding the debate about recovery for emotional distress. The debates have evolved in similar ways: The older skepticism about the genuineness of nonpecuniary injury surfaces less frequently, and the judicial sentiment that only weak or idiosyncratic plaintiffs suffer this type of harm is less apparent in recent cases. Contemporary courts, for example, are less likely to ask the rhetorical question: "What manly mind cares about pain and suffering that is past?"172

Instead, the current controversy seems fixated on the lack of measurability of nonpecuniary loss and the commodification di-

aligned along a single metric without doing violence to our considered judgments about how these goods are best characterized." Cass R. Sunstein, Incommensurability and Valuation in Law, 92 MrCH. L. REV. 779, 796 (1994).

${ }^{170}$ See Randall R. Bovbjerg et al., Valuing Life and Limb in Tort: Scheduling "Pain and Suffering", 83 Nw. U. L. REV. 908, 909-27 (1989) (offering reasons why the current method of assessing damages should be changed). Earlier commentators had a more "no-fault" orientation, arguing that pain and suffering should be abolished as a quid pro quo for eliminating the need to prove negligence. Professor Louis Jaffe's classic article advocating a cautious approach to nonpecuniary damages starts with the assertion that tort liability has already shifted from a fault-based regime to one resting on concepts of insurability. See Louis L. Jaffe, Damages for Personal Injury: The Impact of Insurance, 18 LAW \& CONTEMP. PROBS. 219, 221 (1953) ("If plaintiff has suffered injury of the foreseeable type, it seems that insurability is a much better reason for compensation than fault in the pallid sense in which it is now understood.").

${ }^{171}$ See Finley, supra note 155, at 849 (discussing the importance of the "social functions" of tort law); Thomas C. Galligan, Jr., The Tragedy in Torts, 5 CORNELL J.L. \& PUB. POL'Y 139, 171-75 (1996) (discussing the manner in which tort litigation and, specifically, damage awards are centered on the personalized consideration of the particular plaintiff's plight); Radin, supra note 164, at 83-86 (discussing the importance of the culture-shaping function of law); Steven D. Smith, The Critics and the "Crisis": A Reassessment of Current Conceptions of Tort Law, 72 CORNELL L. REV. 765, $788-89$ (1987) (discussing the importance of legal recognition of noneconomic loss); Sunstein, supra note 169, at 795-812 (discussing the incommensurability of noneconomic loss).

172 The Mediana, 1900 App. Cas. 113, 117 (Eng.), quoted in JOHN G. FLEMING, AN INTRODUCTION TO THE LAW OF TORTS 127 (1968). 
lemma, as discussed above. ${ }^{173}$ Reminiscent of the mental injury/physical injury distinction, there is a tendency to discuss the two types of damages as if they were dichotomous, exaggerating both the ease of measuring pecuniary losses and the difficulty of precisely measuring nonpecuniary losses. Thus, it is not always acknowledged that it is often very difficult to calculate loss of future earning capacity $^{174}$ or other future pecuniary losses. Nor is it always understood that damages for pain and suffering are not wholly unpredictable, but rather depend to a significant degree on the severity of the injury. ${ }^{175}$

Undoubtedly there is considerable variation among different juries in their precise valuation of what might appear to be comparably severe injuries. ${ }^{176}$ This lack of "precision," however, may be regarded as either a major flaw of the torts system or one of its virtues, depending on one's perspective. The growing conventional wisdom among economics-minded academics is that the variation in tort awards proves that the system is inequitable because like harms are not treated alike. ${ }^{177}$ The problem with this general position is that there is no consensus that an individual who suffers a certain type of injury, of a specified severity, will experience the "same" pain and suffering as another person who sustains a similar physical injury. Pain and suffering are highly individualistic and, as one commentator notes, "there is no objective test that measures the severity of the victim's pain-and-suffering injury." ${ }^{178}$ Thus, the failure to achieve precision in the evaluation of similar injuries, from one perspective, looks more like a refined analysis of highly individuated injuries from another perspective. Unless we are to blame plaintiffs for not experiencing

173 See supra text accompanying notes 130-36.

174 See, e.g., Bell, supra note 126 , at 355 (observing that the calculation of future earning capacity is "less mathematically precise than it seems").

175 See Geistfeld, supra note 164 , at 78485 (noting that a number of empirical studies show that "the severity of injury is a good predictor of the size of a pain-andsuffering award").

${ }^{176}$ Mark Geistfeld contends that the current system achieves some degree of "vertical equity" by awarding higher awards to those who suffer more severe types of injuries, but fails to achieve "horizontal equity" because there is a wide variation of recovery for those sustaining presumably similar injuries within the same category. $I d$. at 784.

177 See 2 ENTERPRISE RESPONSIBILITY, supra note 164, at 201-03 (arguing that the problem with pain-and-suffering damages is "the erratic and unpredictable quality of the decisions made about this category of award").

${ }^{178}$ Geistfeld, supra note 164, at 781; see also Daniel J. Gabler, Comment, Conscious Pain and Suffering Is Not a Matter of Degree, 74 MARQ. L. REV. 289, 307 (1991) (noting that the experience of pain is always subjective). 
the modal amount of pain and suffering-in short, for being individuals-there is nothing particularly troubling about variations in pain-and-suffering awards, except, of course, for those cases in which we believe that the jury has awarded an unconscionably high or low award.

It is also not surprising that awards for pain and suffering are highly variable, because there is no external market that fixes the price of such injuries. To my mind, this is a positive feature of our current system, rather than a shortcoming. Reliance on market prices tends to perpetuate disparities correlated to gender, race, and other nonprivileged statuses in society. A critic of market reliance, Richard Abel, has argued against the conventional wisdom that the market ought to be the benchmark by which we judge the virtues of the torts system. He asserts:

Tort damages deliberately reproduce the existing distribution of wealth and income. Those who question its legitimacy may be troubled that the state is using its coercive power to re-create inequality. Furthermore, the cost of preserving privilege is borne by everyone buying liability insurance, purchasing products and services, and paying taxes. Thus, all insured car owners pay the cost of compensating the privileged few who drive Rolls-Royces or earn half a million dollars a year. They also pay for the superior medical care consumed by victims from higher socioeconomic strata.

The nonmarket character of the pain-and-suffering element thus provides a modest corrective to the status quo nature of the current system of tort damages that generally replicates the market. ${ }^{180}$ It provides an opportunity for a jury to express that a plaintiff's injury is significant, even if that person is unemployed, is treated at the charity hospital, or possesses few valuable assets. Whether one is a critic or supporter of nonpecuniary awards may ultimately depend on one's view of the market. For those who start from the premise that the market naturally erodes cultural biases, nonpecuniary damages might seem suspect. If one's starting point is that the market reflects and reinforces cultural biases and systems of privilege, ${ }^{181}$ then nonpecuni-

179 Abel, supra note 125, at 335.

${ }^{180}$ I stress that permitting recovery for pain and suffering is only a modest corrective because often the jury may compute the amount of pain and suffering as a multiple of the victim's economic damages and because, as Abel claims, juries may be more "solicitous of those who have lost privilege than those who never enjoyed it." Id.

${ }^{181}$ The two attitudes towards market systems are mirrored in the respective views of economists and sociologists towards labor markets. Jerry Jacobs explains that "[e]conomists often see labor markets as naturally eroding prejudices and other cul- 
ary damages appear to be a moderating influence in the law that we should be reluctant to jettison or curtail sharply.

Perhaps the judicial and academic skepticism toward noneconomic loss will not soon translate into further erosion of the right to recover for nonpecuniary harm. At the least, however, a hierarchy of types of damages has been erected. In addition to the dichotomies of physical/mental and property/relational, the dichotomy of economic/noneconomic can now be pressed into service to justify decisions regarding tort relief. The recent disparagement of noneconomic loss as fictional-or unreal-legitimates a focus on "real" (i.e., economic) harm.

\section{DISPARATE IMPACT OF HIERARCHIES OF VALUE}

In the abstract, the implicit hierarchies of value look neutral in the sense that they are not explicitly tied to any gender, racial, or other group-based classification. Because all persons have a body, emotions, and personal relationships, it might be thought that everyone possesses "privileged" and "nonprivileged" interests in equal proportions. As they operate in social context, however, I argue that the hierarchies of value tend to have a disproportionately negative impact on women. By disparate impact, I refer to the effects of a facially neutral doctrine on women as a class or on certain subgroups of women. ${ }^{182}$ My basic contention is that the important and recurring injuries in women's lives tend either to be classified more often as lower-ranked emotional or relational harms, or to take the form of noneconomic loss. The ranking thus assigned to "women's injuries"183 makes it more likely that relief will be denied or that recoveries will be devalued.

tural beliefs that are inconsistent with market efficiency. Sociologists, in contrast, tend to see employment systems as adaptable systems that reflect as much as determine the prejudices of the members of a society." Jacobs, supra note 31, at 7.

${ }^{182}$ My use of the term "disparate impact" is not meant to suggest that I believe that all the rules and techniques surrounding disparate impact theory under Title VII should be imported into tort law. Indeed, the elaborate Title VII doctrine governing statistical proof of adverse impact cannot easily be applied to assess the effects of tort rules. Instead, I use "disparate impact" as a term that focuses attention on the effects of a policy on a particular group in society, realizing that there will often be sharp debates about how to recognize and measure such real-world effects.

${ }^{183}$ I put "women's injuries" in quotation marks because I wish to disavow any notion that these injuries are somehow naturally, biologically, or essentially linked to women. Instead, I believe that the disparate impact stems from the particular social roles assigned to women and social obliviousness to the gender dimensions of legal injury. 
Sometimes the disparate impact is a function of the operation of specific legal rules. For example, I will discuss how the various restrictions on "bystander" recovery for mental distress disproportionately harm women, and how a legislative cap on noneconomic damages in health-care-liability actions has an especially harsh effect on lowincome women. Sometimes, however, the disparate impact derives from the absence of law; for example, the absence in many states of a cause of action for loss of filial consortium when a child suffers severe injury. A complete denial of legal recovery to the caretaking parent disparately harms women because the claim of filial consortium is one that implicates a particularly important interest in many women's lives.

In teasing out the disparate impact in tort doctrines, I do not make the claim that every legal rule that has a disparate impact on women should be invalidated. Even under Title VII analysis, policies that produce a disparate impact are lawful if they can be justified as necessary to further other legitimate aims, such as productivity and efficiency. ${ }^{184}$ Instead, my objective is the more modest one of broadening our analysis. The advantage of a disparate impact analysis is that it encourages a critical evaluation of the boundaries of tort law. It asks us to imagine how women evaluate the tragedies and pain in their own lives-for example, the death or injury of a child, the experience of sexual exploitation, or the pain of infertility-compared to the value that is assigned under law by the tort hierarchies.

The three examples of disparate impact I discuss below represent just the beginning of such an analysis of tort law. Each has already been noted in the critical scholarship as an instance of gender bias in tort law. By collecting and grouping the examples, I hope to show how the use of disparate impact analysis allows us to tease out the male bias in tort law, and how we should use such analysis routinely to evaluate the success of tort doctrines or the desirability of tort reforms.

${ }^{184}$ For commentary on the kind of justifications that legitimate use of policies with a disparate impact in the employment context, see Susan S. Grover, The Business Necessity Defense in Disparate Impact Discrimination Cases, 30 GA. L. REV. 387, 389-401 (1996). 


\section{A. Primary Caretakers}

The care of children in our culture has been disproportionately assigned to women. ${ }^{185}$ This means that mothers, grandmothers, and other female relatives tend to spend more time with children than do their male counterparts. As their primary caretakers, women have a greater responsibility for the safety and happiness of children on a daily basis and are likely to place a very high value on the emotional and relational ties to the children under their charge. ${ }^{186}$ This does not mean that men do not care for or love children. Rather, my claim is that the social assignment of child-care responsibilities to women has important implications for tort law.

When a child suffers injury or dies, it can be expected that those who have special responsibility for caring for the child will also suffer a grievous injury. After a serious accident, the caretaker must learn to deal with the child's resulting physical disability and the enormous change in daily routine that often occurs. Additionally, the injury is likely to produce a significant change in the quality of the relationship; the caretaker will often experience grief, guilt, and anxiety as a response to the tragedy. For both the caretaker and the child, such an accident can be a life-altering event. ${ }^{187}$

Tort law most often treats the caretaker's losses as derivative or secondary, failing to recognize the full extent of the caretaker's relational and emotional loss. ${ }^{188}$ Lucinda Finley has noted that the law's

185 See Martha L.A. Fineman, Masking Dependency: The Political Role of Family Rhetoric, 81 VA. L. REV. 2181, 2199 (1995) (citing studies showing that "[w]omen continue to bear the "burdens of intimacy" including the vast bulk of child care and housework). Women have greater responsibility for the care of both dependent children and other dependent relatives. See Nadine Taub, From Parental Leaves to Nurturing Leaves, 13 N.Y.U. REV. L. \& SOC. CHANGE 381, 383 (1984-1985) (advocating the adoption of comprehensive caregiver work-leave programs). Joan Williams has analyzed women's disparate burden for child care as stemming from men's greater willingness to delegate the care of their children to others. To some extent, in high-income families, other women can be hired to perform domestic services and child care. In lowerincome families, mothers and other relatives are left with a greater burden of housework and child care. See Joan Williams, Is Coverture Dead? Beyond a New Theory of Alimony, 82 GEO. L.J. 2227, 2236-40 (1994).

${ }_{186}$ See Mary Becker, Maternal Feelings: Myth, Taboo, and Child Custody, 1 S. CAL. REv. L. \& WOMEN's STUD. 135, 152-58 (1992) (discussing the intense emotional involvement of primary caretakers who are most often women).

${ }^{187}$ See, e.g., Regina Graycar, Before the High Court: Women's Work: Who Cares?, 14 SYDNEY L. REV. 86, 86-87 (1992) (detailing the hardship of a mother caring for her disabled daughter).

${ }^{183}$ For discussions of the evolution of the caselaw on compensation for caretakers' losses, see Susan J.G. Alexander, A Fairer Hand: Why Courts Must Recognize the Value of a 
reluctance to recognize a cause of action for loss of filial consortium has a disproportionate impact on women in their roles as the primary caretakers of children. ${ }^{169}$ The denial of the claim also devalues the activity of raising children. Admittedly, the child's "primary" claim may include an amount for medical and other rehabilitative expenses associated with the child's physical injury, and for the mental and relational harm suffered by the child. ${ }^{190}$ But the devastating impact the accident has on the daily life of the caretaker is eclipsed when there is no separate claim for loss of consortium. In popular culture, the role of the "soccer mom"191 is valorized and much is made of the importance of women making it their first priority to raise children. However, the hierarchy of tort claims does not so highly value the contributions of parents and other caretakers: The most painful event in a caretaker's life may not be actionable in tort.

Similar to the devaluation processes discussed in the beginning of this Article, ${ }^{192}$ the devaluation of child rearing harms individuals of both sexes who devote a significant portion of their lives to this activity. This gender-linked devaluation of an activity traditionally associated with women, and still carried on disproportionately by women, resembles the dynamic underlying comparable worth theory. ${ }^{193}$ In

Child's Companionship, 8 T.M. CoOLEY L. REv. 273, 287-96 (1991); Jean C. Love, Tortious Interference with the Parent-Child Relationship: Loss of an Injured Person's Society and Companionship, 51 IND. L.J. 590 (1976).

${ }^{189}$ See Finley, supra note 88, at 50.

${ }^{190}$ However, a minority of jurisdictions still do not permit the injured party to recover for the costs of home health care provided gratuitously by a member of a family. Thus, in some cases, a mother's or other caretaker's full-time care of a grievously disabled accident victim is given no legal recognition. See, e.g., Peterson v. Lou Bachrodt Chevrolet Co., 392 N.E.2d 1, 5 (IIl. 1979) (citing as still controlling the holding that "a personal injury plaintiff could not recover for the value of nursing services rendered by the plaintiff's family" (citing Jones \& Adams Co. v. George, 81 N.E. 4 (Ill. 1907))). For a case representing the majority viewpoint, see Bandel $v$. Friedrich, 584 A.2d 800, 802-03 (N.J. 1991) (granting compensation for a mother's gratuitous care in her son's tort claim). The New Jersey Supreme Court recognized that denying such recovery could "discriminate against the poor, who presumably would be affected more than the rich, who could afford nursing services." Id.

${ }^{191}$ See Ann Hulbert, Angels in the Infield, NEW REPUBLIC, Nov. 18, 1996, at 46 (discussing the soccer mom as a new social category).

${ }^{192}$ See supra notes 30-54 and accompanying text.

193 Martha Fineman has created the term "derivative dependency" to describe the devalued status of caretakers in our society. Her contention is that, like their charges, caretakers of children, the elderly, and disabled persons become dependent on society for resources to enable them to perform this essential labor. Because they often work in the "uncompensated sphere of the private family," the value of their labor is not given legal recognition. See Martha A. Fineman, The Nature of Dependencies and Welfare "Reform", 36 SANTA CLARA L. REV. 287, 292-94 (1996). 
this way, tort law contributes to the inferior status of women's work and arguably perpetuates the assignment of this work to women.

In addition, because even those states that permit loss of filial consortium claims limit the cause of action to biological or adoptive parents, the harm to others who take on primary caretaking roles gets no legal recognition. This limitation likely has a disproportionate impact on African-Americans and other ethnic groups in which extended family members-most often grandparents-often have the primary responsibility for raising children. ${ }^{194}$ This racially disproportionate impact was recognized in a related context in 1991 when Louisiana codified its rules regarding recovery for bystanders who witness an injury to a family member. The original bill restricted recovery to members of the nuclear family, consistent with the state's scheme for wrongful death recovery. ${ }^{195}$ The bill was amended to include grandparents as potential plaintiffs when an African-American legislator pointed out that he had been raised by his grandparents and that such a pattern was common in the black community. ${ }^{196}$ However, Louisiana did not also expand its rules regarding who may recover for loss of consortium to include grandparents as well, creating the anomaly that only grandparents who witness an injury have a legally recognized cause of action. Similarly, most states have left the scope of the consortium claim to the courts, which have refused to extend consortium claims beyond the nuclear family, perhaps not fully appreciating that families may be defined differently in different communities. $^{197}$

Finally, restrictive doctrines like the "danger zone" rule, governing recovery for negligent infliction of mental distress, tend to hurt mothers disproportionately as the classic "bystanders." The dangerzone limitation denies recovery to a parent who witnesses her child's negligent killing or injury, unless the parent's life is also imperiled. ${ }^{198}$

${ }^{194}$ See Karen Czapanskiy, Grandparents, Parents and Grandchildren: Actualizing Interdependency in Law, 26 CONN. L. REV. 1315, 1326-27 (1994) (noting that African-

American grandparents are twice as likely as white grandparents to share a home with a grandchild and to take on a parental role).

${ }^{195}$ See LA. CIV. CODE ANN. art. 2315 (West 1997). Under Louisiana law, wrongful death beneficiaries consist of spouses, parents, and siblings. Louisiana law afforded no claims for loss of consortium until the 1982 amendment to article 2315.

196 Telephone Interview with Thomas Galligan, Professor, Louisiana State University Law School (Nov. 1996) (discussing the history of article 2315.6 of the Louisiana Civil Code, which provided for bystander recovery in mental distress cases).

${ }^{197}$ See supra text accompanying notes $145-47$.

${ }^{193}$ See supra notes $102-03$ and accompanying text. 
My research on bystander cases ${ }^{199}$ details how this legal distinction between "fear for oneself" and "fear for another" discounts the importance of a caretaker's relationship to a child. ${ }^{200}$ The distinction also denies legal recognition for one of the most highly foreseeable impacts of the negligent killing or death of a child: that a nearby parent or other person responsible for the child will be traumatized when they witness the accident. The witnesses to accidents involving children are frequently female caretakers. Particularly because most jurisdictions deny recovery for loss of filial consortium, the restrictions on bystander recovery further marginalize the caretaker's injury, providing no protection for either the relational or the emotional aspects of the harm.

\section{B. Sexual Harassment}

Tort law has never provided a solid basis for recovering for sexual harassment. This significant gap in the law is largely a product of the nonprivileged status of emotional harm. Although some harassment takes the form of physical contact amounting to battery or assault, the far more common type of harassment consists of claims of hostile working or educational environments, ${ }^{201}$ and involves verbal conduct and patterns of abuse that do not fall neatly into the traditional intentional tort categories. It is telling that no legal category captures the full dimensions of sexual harassment as an injury. Tort law treats it primarily as a dignitary harm under the rubric of emotional distress.

The numerous empirical studies of sexual harassment in the workplace indicate that the vast majority of harassment victims are women, ${ }^{202}$ although there is now growing recognition of the phe-

${ }^{199}$ See Chamallas with Kerber, supra note 100, at 837-41, 851-64 (discussing the legal origins and development of the "bystander rule").

${ }^{200}$ For discussions of the importance of the caretaker's relationship to a child or other dependents and the loss suffered when a child is negligently injured, see Alexander, supra note 188, at 333-37, and Finley, supra note 88, at 50-51.

${ }^{201}$ Sexual harassment cases are generally classified into two types: quid pro quo and hostile environment cases. In quid pro quo cases, the harassment is directly linked to the grant or denial of an economic benefit. In hostile working environment cases, there is often no tangible economic harm. Instead, severe and pervasive harassing conduct affects the plaintiff's everyday working conditions and often gives rise to emotional distress. See BARBaRa LindemanN \& DAVD D. KADUE, SEXUAL HaRASSMENT IN EMPLOYMENT LAW 8-9 (1992) (comparing quid pro quo and hostile environment claims).

${ }^{202}$ Two studies of the federal workforce found that $42 \%$ of women experienced some form of harassment during a two-year period. See DEBORAH L. SIEGEL, NATIONAL COUNCIL FOR RESEARCH ON WOMEN, SEXUAL HARASSMENT: RESEARCH AND RESOURCES 
nomenon of same-sex sexual harassment of men by male supervisors and coworkers. ${ }^{203}$ The law's treatment of sexual harassment is thus of special importance to women; any lack of protection tends to have a profound disparate impact on women.

Catharine MacKinnon was the first to recognize the inadequacy of tort law as a remedy for sexual harassment. Indeed, her argument for recognition of a civil rights claim under Title VII was based, in part, on the structural deficiencies of tort law. ${ }^{204}$ When making claims for intentional infliction of mental distress, victims of sexual harassment face an initial hurdle of proving that the defendant's behavior was "outrageous." Although some plaintiffs have overcome this obstacle, ${ }^{206}$ most courts still do not regard sexual harassment as per se outrageous conduct, ${ }^{207}$ with the result that the scope of liability under

9 (Susan A. Hallgarth \& Mary Ellen S. Capek eds., 1991). In comparison, from 1992 to 1996, approximately $10 \%$ of the sexual harassment claims filed with the EEOC were filed by men. See Telephone Interview with EEOC Headquarters (Mar. 3, 1998).

${ }^{203}$ See Oncale v. Sundowner Offshore Servs., Inc., No. 96-568, $1998 \mathrm{WL} 88039$, at *5 (Mar. 4, 1998) (holding that same-sex harrassment is actionable under Title VII). Prior to Oncale, the federal courts had issued a spate of decisions involving same-sex harassment, many involving the harassment of gay men or men perceived to be gay. See, e.g., Doe v. City of Belleville, 119 F.3d 563, 595 (7th Cir. 1997) (finding same-sex harassment actionable), petition for cert. filed, 66 U.S.L.W. 3308 (U.S. Oct. 15, 1997) (No. 97-669); Quick v. Donaldson Co., 90 F.3d 1372, 1379 (8th Cir. 1996) (finding that same-sex harassment is actionable if members of one gender group are targeted); Dillon v. Frank, No. 90-2290, 1992 WL 5436, at *7 (6th Cir. 1992) (holding that Title VII does not support a cause of action for discrimination based on sexual orientation); Goluszek v. Smith, 697 F. Supp. 1452, 1456 (N.D. IIl. 1988) (holding that sexual harassment by a fellow male worker is not actionable).

204 See MACKINNON, supra note 43, at 16474. MacKinnon argued that the highly individualistic character of tort law makes it ill-suited to address the social harm of sexual harassment, claiming that " $[t]$ he essential purpose of tort law ... is to compensate individuals one at a time for mischief which befalls them as a consequence of the one-time ineptitude or nastiness of other individuals." Id. at 172. Now that the harm of sexual harassment has become established under Title VII law, however, it has migrated into tort law and gained greater legitimacy. The question is no longer whether tort law or civil rights law is the best forum to address the harm, but why tort law has not given fuller protection for this recurring injury.

${ }_{205}$ See LINDEMANN \& KADUE, supra note 201, at 353-55 (discussing proof of outrageousness in sexual harassment cases).

${ }^{206}$ See Jean C. Love, Discriminatory Speech and the Tort of Intentional Inftiction of Emotional Distress, 47 WASH. \& LEE L. REV. 123, 138-42 (1990) (discussing cases in which the claim of intentional infliction of emotional distress was successful).

${ }^{207}$ For commentary on the "outrageousness" requirement as it affects sexual harassment victims, see Mae C. Quinn, Note, The Garden Path of Boyles v. Kerr and Twyman v. Twyman: An Outrageous Response to Victims of Sexual Misconduct, 4TEx. J. WOMEN \& L. 247, 253-58 (1995) (arguing that this requirement makes an intentional infliction of emotional distress claim very difficult to win); Krista J. Schoenheider, Comment, $A$ Theory of Tort Liability for Sexual Harassment in the Workplace, 134 U. PA. L. REV. 1461, 
tort law is even more restrictive than that provided under Title $\mathrm{VII}^{208}$ and similar state antidiscrimination statutes.

This disparity in coverage has substantive as well as procedural disadvantages, because the newly expanded civil rights remedies under Title VII impose a cap on compensatory and punitive damages for harassment victims. ${ }^{209}$ This means that, unless the plaintiff can meet the more onerous requirements of proof for intentional infliction of mental distress, she may not receive full compensation for her injury. Moreover, outside the employment and educational contexts, there is generally no special statutory protection against sexual harassment. Tort law often provides the sole measure of protection for women who are harassed on the street, ${ }^{210}$ or who suffer from sexual exploitation by professionals such as divorce lawyers and physicians. ${ }^{211}$

Perhaps even more significant than the special hurdles placed on the recovery for intentional infliction of mental distress is the law's failure to provide consistent recognition of claims for negligent infliction of mental distress stemming from sexual exploitation and harassment. The Texas Supreme Court recently debated the gender impact of recognizing such claims. In Boyles $v$. Kerr, the majority denied the mental distress claim of a nineteen-year-old woman who suffered

1462-63 (1986) ("In the absence of at least a threat of physical injury or other conduct a court deems to be sufficiently 'outrageous,' a plaintiff can rarely rely on traditional tort theories for adequate compensation.").

${ }^{263}$ Although harassment victims proceeding under Title VI need not prove that their harassment resulted in severe mental distress, see Harris v. Forklift Sys., Inc., $\mathbf{5 1 0}$ U.S. 17, 21 (1993), they must establish that the defendant's conduct was "unwelcome," "severe or pervasive," and that the employer knew or should have known of the behavior and failed to take prompt, corrective action. The most frequently cited case establishing the elements of proof is Henson v. City of Dundee, 682 F.2d 897 (11th Cir. 1982), discussed in LINDEMANN \& KADUE, supra note 201, at 168-99.

${ }^{209}$ The Civil Rights Act of 1991 amended Title VII to permit plaintiffs alleging intentional discrimination to try their cases before a jury and to receive compensatory and punitive damages. Damages are capped, however, at $\$ 50,000$ to $\$ 300,000$, depending on the size of the employer. See 42 U.S.C. $\$ 1981 \mathrm{a}(\mathrm{a})(1),(\mathrm{b}),(\mathrm{c})(1)$ (1994). Prior to the $1991 \mathrm{Act}$, there was no right to a jury trial and no recovery of compensatory or punitive damages.

${ }_{210}$ See Cynthia G. Bowman, Street Harassment and the Informal Ghettoization of Women, 106 HARV. L. REV. 517, 548-80 (1993) (analyzing criminal and civil laws that may address "street harassment," and proposing new methods to deal with this problem).

${ }^{211}$ For a discussion of tort liability of professionals in sex abuse cases, see Denise LeBoeuf, Psychiatric Malpractice: Exploitation of Women Patients, 11 HARV. WOMEN's L.J. 83, 95-116 (1988) (examining judicial and statutory treatment of liability of psychotherapists for exploiting female patients); Thomas Lyon, Sexual Exploitation of Divorce Clients: The Lawyer's Prerogative?, 10 HARV. WOMEN's L.J. 159, 188-96 (1987) (discussing the viability of a cause of action brought by sexually exploited clients against their divorce lawyers based on breach of fiduciary duty). 
mental distress when she learned that the defendant had secretly videotaped them having sexual intercourse and then showed the tape to his friends. ${ }^{212}$ Over the strong dissent of Justice Spector, ${ }^{213}$ the only woman on the Texas Supreme Court, the majority abolished the claim for negligent infliction of mental distress. ${ }^{214}$ Spector pointed out that the majority's action had a disparate effect on women as a class and stressed that recovery under intentional tort theories was “'seldom successful.",215 Her opinion represents the most thorough judicial analysis of gender-linked devaluation through marginalization of claims for mental distress:

It is no coincidence that both this cause and Boyles involve serious emotional distress claims asserted by women against men. From the beginning, tort recovery for infliction of emotional distress has developed primarily as a means of compensating women for injuries inflicted by men insensitive to the harm caused by their conduct. In "[t]he leading case which broke through the shackles," [Wilkinson v. Downton, 2 Q.B.D. 57 (Eng. 1897)], a man amused himself by falsely informing a woman that her husband had been gravely injured, causing a serious and permanent shock to her nervous system. Similarly, in the watershed Texas case, [Hill v. Kimball, 13 S.W. 59 (Tex. 1890)] a man severely beat two others in the presence of a pregnant woman, who suffered a miscarriage as a result of her emotional distress....

...

I do not argue that women alone have an interest in recovery for emotional distress. However, since the overwhelming majority of emotional distress claims have arisen from harmful conduct by men, rather than women, I do argue that men have had a disproportionate interest in downplaying such claims.

Brutish behavior that causes severe injury, even though unintentionally, should not be trivialized. Foreclosing recovery for such behavior may prevent litigation of frivolous claims; but it also denies redress in exactly those instances where it is most needed. ${ }^{216}$

The availability of a negligence cause of action is especially important in cases of sexual harassment because defendants often claim

${ }^{212} 855$ S.W.2d 593, 594 (Tex. 1993) (reversing a verdict for the plaintiff on grounds that in Texas there is no general duty not to inflict emotional distress).

${ }^{213}$ Spector's dissent can be found in the companion case of Tuyman $v$. Tuyman, 855 S.W.2d 619, 640 (Tex. 1993) (Spector, J., dissenting).

${ }^{214}$ Spector's opinion is described at length in Leslie Bender, Teaching Torts as if Gender Matters: Intentional Torts, 2 VA. J. SoC. POL'Y \& L. 115, 146-50 (1994).

${ }^{215}$ Tuyman, 855 S.W.2d at 643 (Spector, J., dissenting) (quoting language used in the majority opinion, 855 S.W.2d at 631 ).

${ }^{216}$ Id. at 642-44 (Spector, J., dissenting) (footnote omitted) (quoting William L. Prosser, Insult and Outrage, 44 CAL. L. REV. 40, 42 (1956)). 
that they intended no harm, that they were merely joking, or that they did not fully appreciate the impact of their conduct. Empirical research documents a "two worlds" phenomenon in which men and women often make significantly different assessments of the acceptability of sexually related conduct. Generally, women are more likely to regard sexual conduct in the workplace as offensive, while men are more likely to mistake friendliness for seduction. ${ }^{217}$ Negligence liability is designed to assure that a minimally acceptable level of conduct is imposed through legal sanctions, thus recognizing that the greatest harms are often inflicted through ignorance, carelessness, or disregard of the interests of others. When the law withholds this measure of protection from sexual harassment victims, it fails to respond adequately to a serious, recurring injury in the lives of women.

\section{Health Care}

In the past two decades, "tort reform" has come to mean initiatives to limit tort liability in response to what some business representatives and others regard as a litigation explosion, composed of frivolous suits and excessive jury awards. Despite several very convincing studies $^{218}$ disputing the existence of the crisis and defending the jury system, the pressure to cut back on plaintiffs' rights has not abated. Starting at the state level and now gaining momentum at the federal

${ }^{217}$ See Barbara A. Gutek, Understanding Sexual Harassment at Wonh, 6 NOTRE DAME J.L. ETHICS \& PUB. POL'Y 335, 336-57 (1992) (surveying the social-science research conducted on sexual harassment in the workplace). The different perception is not the result of any biological or natural differences in the genders toward sex, but rather stems from the different social position of men and women. Thus, researchers hypothesize that men's and women's perceptions of sexual harassment reflect their own self-interest. It is in men's interest to see relatively little sexual harassment, because men are most often the offenders, whereas it is in women's self-interest to see relatively more sexual harassment, because women tend to be the victims in sexual harassment encounters. Women, as a group, also face greater risks of sexual violence, and as relative newcomers to the workforce, their status is jeopardized in sexualized environments. See Kathryn Abrams, Gender Discrimination and the Transformation of Workplace Norms, 42 VAND. L. REV. 1183, 1205 (1989) (arguing that women's social position influences their views of sexual conduct in the workplace).

${ }^{218}$ See Michael J. Saks, Do We Really Know Anything About the Behavior of the Tort Litigation System-And Why Not?, 140 U. PA. L. REV. 1147, 1149 (1992) (arguing that the available empirical evidence on the behavior of the tort litigation system is inadequate for drawing trustworthy conclusions); Neil Vidmar \& Jeffrey J. Rice, Assessments of Noneconomic Damage Awards in Medical Negligence: A Comparison of Jurors with Legal Professionals, 78 IOWA L. REV. 883, 890-901 (1993) (reporting on a study that showed no great disparity between juror awards for pain and suffering and disfigurement and awards rendered by experienced legal professionals). 
level, ${ }^{219}$ proponents have targeted products liability and medical malpractice as sites for reform, with a particular focus on noneconomic and punitive damages. For example, one federal proposal that has received much attention would cap noneconomic losses in "health care liability actions," defined as cases of medical negligence or products liability cases involving a medical product. ${ }^{220}$ There are also proposals to cap punitive damages, either by imposing a dollar limit (e.g., $\$ 250,000$ ), or by limiting punitive damages to two or three times the economic loss, regardless of the wealth or size of the defendant. ${ }^{221}$

For the first time in the long debate over tort reform, critics of the cutbacks have begun to assess the gender impact of the various proposals. The most extensive study, by Thomas Koenig and Michael Rustad, demonstrates that women stand to lose more when "nonprivileged" types of damages are curtailed, particularly in actions involving health care. ${ }^{222}$ Their study revealed that two out of three plaintiffs receiving punitive damages in medical malpractice litigation are women, ${ }^{223}$ often in gender-linked cases involving mismanaged childbirth, cosmetic surgery, sexual abuse, and neglect in nursing homes. ${ }^{224}$ Critics have also noted that much of mass tort litigation has centered on women's reproductive health and other gender-linked injuries, including the Dalkon Shield, Norplant, super-absorbent tampons, and breast implant litigation. Measures targeting noneconomic awards for health-care liability thus threaten to curtail this new focus on gender-specific injuries. ${ }^{225}$

The Koenig and Rustad study also showed that capping noneconomic damages for pain and suffering and loss of enjoyment of life would have a disparate effect on women because the noneconomic portion of the tort award is crucial for women plaintiffs. Because of their depressed wages and unpaid responsibility for child

219 The latest products liability reform bill combines caps on punitive damages with abolition of joint and several liability for pain and suffering and other noneconomic injuries. See Kenneth Jost, Tort Issues Resurrected, A.B.A. J., Mar. 1997, at 18 (describing the fate of the latest tort-reform-liability bill, S. 79, 105th Cong. (1997)).

${ }^{220}$ The bill was vetoed by President Clinton. For a discussion of the proposal, see Finley, supra note 155 , at 864 .

${ }^{221}$ See id.

222 Koenig \& Rustad, supra note 14, at 29-87.

${ }^{223}$ See id. at 59.

${ }^{224}$ See id. at 62-77.

${ }^{225}$ See Finley, supra note 155, at 863 (discussing the importance of nonpecuniaryloss damages for female plaintiffs in Dalkon Shield and other medical-products litigation). 
care and housekeeping, women plaintiffs, as a group, tend to have smaller economic losses than men of the same age. ${ }^{226}$ Even physical injuries to women may not translate into large awards for medical expenses, particularly if there is no current treatment for the condition. Thus, when a housewife suffers reproductive injury from being forced to undergo a hysterectomy caused by damage from an IUD, the primary measure of her injuries will be noneconomic. ${ }^{227}$ The proposed cap on noneconomic damages in health-care actions thus would have a doubly negative effect on women because it would restrict an important element of damages in the very cases women tend to bring.

This latest round in the debate over tort reform underscores the significance of noneconomic damages to women. Noneconomic damages serve to offset the disproportionately low value placed on women's claims when the measures are solely economic. They also serve as the only means of expressing the value of certain genderlinked reproductive injuries, such as the loss of fertility. The recent legislative and judicial trend to solidify the implicit hierarchy of damages and to privilege economic over noneconomic damages thus has the potential to further slant the torts system against women's interests.

\section{SOCIAL CONSTRUCTION OF CATEgORIES: THE CONCEPTUAL VICIOUS CYCLE}

My claim that the basic tort hierarchies of value are "gendered" to the disadvantage of women creates something of a paradox. Contemporary judges and legislators most often profess a commitment to gender equality and neutrality; few would openly rely on gender differences to justify either denying women's claims or discounting their injuries. This suggests that the mechanisms that maintain the gendered hierarchies of value are more subtle, that devaluation is accomplished through a nondeliberate process that may not look like

${ }^{226}$ See supra text accompanying notes 55-87 (describing gender and race bias in computing loss of future earning capacity). Given the existing bias with respect to the economic portion of the damage award, curtailment of noneconomic damages would intensify the disparate impact.

${ }_{277}$ See Pamela Anagnos Liapakis, Tort Reform Could Leave Women Shortchanged, NAT'L L.J., July 24, 1995, at C2, C2 (predicting that tort reforms which limit noneconomic damages will burden female plaintiffs more than male plaintiffs). 
prejudice, hostility, or bias. The source of the bias is not bigotry, but rather cognitive processes that influence everyone's thinking. ${ }^{228}$

It is at this point that critical theory figures most explicitly in my analysis. ${ }^{229}$ As I have described the hierarchies of value, they not only set up a ranking of different types of injuries and types of damages, they also establish pairs of opposites or dualisms. Embedded in the hierarchies are three contrasting categories: physical/emotional, property/relational, and economic/noneconomic. It is important to notice that these categories are themselves gendered. By gendered, I mean that if we were asked to link each type of damage or harm with the adjective "male" or "female," there would be widespread agreement that the left side of the pair (physical, property, economic) should be labeled "male," while the right side of the pair (emotional, relational, noneconomic) should be labeled "female."

Many people, myself included, might wish to resist the normative implications of gendering the pairs in this way: we would dispute that women are more emotional or that men have less concern for relationships. Feminist and critical race scholars have also repeatedly pointed out that the labels do not fit many subgroups of women. ${ }^{230}$ The stereotypes of domesticity, modesty, and emotionality do not often attach to African-American and working class women, for exam-

${ }^{223}$ Some of the most illuminating scholarly discussions of racism, sexism, and other discriminatory conduct have focused on social cognition theory and the importance of categorization. See, e.g., Armour, supra note 25, at 750-59 (discussing the habit-like aspects of group stereotyping); Krieger, supra note 75, at 1186-17 ("In a culture in which race, gender, and ethnicity are salient, even the well-intentioned will inexorably categorize along racial, gender, and ethnic lines.").

${ }^{229}$ My analysis most closely resembles the process described by Frances Olsen in her essay The Sex of Law, in the "classic" text of the critical legal studies movement, THE POLITICS OF LAW, supra note 17 , at 453.

${ }^{250}$ The larger theoretical debate addresses "essentialism" both in mainstream and feminist theory. The term "essentialism" refers to the idea that there is some common, underlying attribute or experience shared by all women, independent of race, class, sexual orientation, or other aspects of their particular situation. One form of gender essentialism, known as "false universalism," uses an unstated norm of the most privileged group of women, that is, white, middle-class, heterosexual women, as if it were applicable to women generally. See Katharine T. Bartlett, Gender Law, 1 DUKE J. GENDER L. \& POL'Y 1, 15-17 (1994) (defining "essentialism"). Post-essentialist critics have shown how even feminist theory is tainted by essentialist premises. See Patricia A. Cain, Feminist Jurispredence: Grounding the Theories, 4 BERKELEY WOMEN'S L.J. 191, 206 (1989-1990) ("Scholarship that nominally recognizes differences, but still categorizes 'woman' from a single perspective is stuck in the assimilationist/essentialist trap."); Angela P. Harris, Race and Essentialism in Feminist Legal Theory, 42 STAN. L. REV. 581, 585-605 (1990) (criticizing the scholarship of Catharine MacKinnon and Robin West as essentialist). 
ple, who have always worked outside their own homes and are often stereotyped as coarse and material. ${ }^{231}$ However, my point in linking the basic tort categories to their respective gender is to expose the dominant structures of thought, in part because such structures do not describe reality for most people. The dominant ideology is not attuned to the life experiences, perspectives, or situation of the most marginalized groups in society. Instead, the stereotypes of "women" are likely to reflect the dominant thinking about white, heterosexual, middle-class women, the most privileged subgroup of women. ${ }^{232}$ All persons, however, must learn the meaning of the dominant categories to live in a world not of our own making. ${ }^{233}$ The very fact that at some level we "know" that emotions, relations, and noneconomic damages are gendered female is highly significant. This conceptual linkage affects the way we see the world, including how we categorize injury and harm.

In my study of tort law, the phenomenon that I have found to be at once the most interesting and the most infuriating is what I describe here as the conceptual vicious cycle. This perceptual process categorizes injury sustained by women as emotional, relational, or nonpecuniary, even when the same injury could, as a matter of logic, be characterized as physical, pertaining to property, or pecuniary. In deciding how to categorize a loss, we look not only in some abstract way at the nature of the injury, but also at who we believe is suffering the loss. The conceptual vicious cycle makes the gender of the prototypical plaintiff affect the way we conceptualize the nature of the harm.

The perceptual process I hypothesize here is akin to the process that occurs when people interpret ambiguous behavior. Social psychologists have conducted experiments measuring human perception, asking their subjects, for example, to describe an interaction be-

221 For critiques of separate-spheres literature that applies feminine stereotypes of domesticity, frailty, and delicacy as if they attached to all women, see Kimberle Crenshaw, Demarginalizing the Intersection of Race and Sex: A Black Feminist Critique of Antidiscrimination Doctrine, Feminist Theory and Antiracist Politics, 1989 U. CHI. LEGAL F. 139,155 ("[A]ttempt[ing] to debunk ideological justifications for women's subordination offers little insight into the domination of Black women. $\left.{ }^{n}\right)$.

222 See ElIZABETH V. SPELMAN, INESSENTIAL WOMAN: PROBlems of EXCLUSION IN FEMINIST THOUGHT 3 (1988) (“[T] he focus on women 'as women' has addressed only one group of women-namely, white middle-class women of Western industrialized countries.").

${ }^{235}$ Even nondominant groups know, and to some extent, internalize, the prevailing stereotypes and generalizations about them. See Lawrence, supra note 24, at 351. 
tween two people involving a poke or a shove. ${ }^{234}$ The action is ambiguous, in the sense that it could possibly be classified as benign (dramatizes, gives information, plays around) or threatening (aggressive, violent, mean). The studies indicate that the race of the actor is important in determining how the action will be interpreted or categorized. Thus, whites tend to interpret the ambiguous behaviors of black actors as being more threatening and more hostile than the same behavior undertaken by white actors. The race of the actor serves to activate a stereotype or cognitive association, such as linking blacks to violence, that gives meaning to the behavior. The identity of the actor affects how we perceive the nature of the action.

Moreover, if we accept that the gender of the prototypical plaintiff may likewise affect legal categorization, legal categorization itself begins to look like an active process that involves human choice. In this way, we can see that the basic legal categories in tort law are socially constructed. The deep structures of tort law are indeed "manmade." This means, of course, that if we choose, they can also be reconstructed to fit better our notions of gender equity and fairness.

I first understood this process behind the social construction of basic tort categories when I read the opinions in Lynch $v$. Knight, the old English case that stands for the proposition that mental distur-

234 The two major studies tested for racially based schemas in interpreting ambiguous information and behavior. In the first study, white students were shown a videotape of two male students discussing alternative solutions to a problem, ending in an ambiguous shove. The subjects were asked to categorize the behavior using the following ten categories: dramatizes, gives information, gives opinion, gives suggestion, asks for information, asks for opinion, asks for suggestion, playing around, aggressive behavior, and violent behavior. When the protagonist was black and the victim white, 75\% characterized the behavior as violent. When both the protagonist and the victim were black, $69 \%$ perceived violence. For white protagonists, the characterization of violence was much lower, only $13 \%$ when the victim was white, $17 \%$ when the victim was black. See Birt L. Duncan, Differential Social Perception and Attribution of Intergroup Violence: Testing the Lower Limits of Stereotyping of Blacks, 34 J. PERSONALITY \& SOC. PSXCHOL. 590, 595-97 (1976), discussed in Armour, supra note 25, at 752-54 \& n.90.

The second study asked school-age children to evaluate the behavior of a child depicted in a cartoon and described verbally. The verbal description of the scene was: "Mark was sitting at this desk, working on a social studies assignment, when David started poking him in the back with the eraser end of his pencil. Mark just kept on working. David kept poking for a while, and then he finally stopped." The subjects rated the behavior as playful, friendly, mean, or threatening. The results confirmed the earlier study, judging the behavior as more threatening or mean if the poking was done by a black child. See H. Andrew Sagar \& Janet Ward Schofield, Racial and Behavioral Cues in Black and White Children's Perceptions of Ambiguously Aggressive Acts, 39 J. PERSONALITY \& SOC. PSYCHOL. 590, 593-95 (1980), discussed in Krieger, supra note 75, at 1202-03. 
bance alone does not qualify as a legally cognizable harm. ${ }^{235}$ Lord Campbell's opinion was the most revealing. In it, he discussed the question of why men, but not women, could sue for "criminal conversation," the claim brought by a husband against a man who had intercourse with the plaintiff's wife. Lord Campbell sincerely believed that when a wife was not faithful to her husband, the husband suffered something akin to a permanent loss of property. ${ }^{236}$ For Lord Campbell, the loss of the husband's exclusive sexual access to his wife was a material harm. It was property-like in nature. However, when he analyzed the losses the wife suffered from her husband's sexual betrayal, he saw only hurt feelings and emotional harm. ${ }^{237}$ The court described harm to the wife as merely subjective and intangible. ${ }^{233}$ Today, most people would contend that adultery is adultery, genderneutral. In 1861, the gendered dimensions of adultery were apparently more visible.

The conceptual vicious cycle is still at work in the social construction of tort categories. I offer three more recent examples of the cycle as it affects the three pairs of dualisms that form the hierarchies of value.

\section{A. Physical/Emotional}

When experienced by women, the physical can become the emotional. My study of fright-based injuries analyzed the classic "mental distress" cases involving female plaintiffs who suffered miscarriages and stillbirths as a result of emotional trauma. ${ }^{239}$ In a very real sense, these plaintiffs suffered physical injuries. As many of the early commentators pointed out, their cases could easily have been determined by the same principles and doctrines applied to ordinary negligence litigation. ${ }^{240}$ Instead, their claims were classified as emotional harm cases. In this one class of litigation, the law fixed on fright, the mechanism of the injury, rather than on the ultimate physical consequences of the defendant's actions. ${ }^{241}$ Moreover, once classified as emotional, the various restrictive doctrines governing this unprivi-

\footnotetext{
2s5 11 Eng. Rep. 854, 859 (H.L. 1861).

${ }^{205}$ See id. at 860 (opinion of Lord Campbell).

${ }^{237}$ See id. (opinion of Lord Campbell).

${ }^{209}$ See id. at 863 (opinion of Lord Wensleydale).

289 See Chamallas with Kerber, supra note 100 , at 814 .

${ }^{240}$ See id. at $834-37$ (discussing the views of Francis Bohlen and Herbert Goodrich).

${ }^{241}$ See id. at 834 (describing fright as the "mechanism" of the injury, which might also produce physical consequences).
} 
leged category of harm reduced the likelihood of recovery. To some extent, the classification of fright-based physical harms as "mental distress" persists to this day, as the organization of the basic torts casebooks and treatises demonstrates. ${ }^{242}$ When faced with a choice-a choice that is inevitable when we construct categories-the law matched the type of injury (emotional) to the prototypical plaintiff (pregnant woman).

Lucinda Finley has also discerned the operation of the vicious cycle at work in the law's treatment of women's reproductive and sexualized injuries. ${ }^{243}$ Finley asserts that tort law tracks the medical profession and tends to regard harm "to a woman's reproductive system or sexualized part of her body, like her breasts," ${ }^{244}$ as an emotional, rather than a physical, injury. As an example, she cites the prominent case of Payton v. Abbott Labs, in which the court refused to allow women who were injured by the "anti-miscarriage" drug DES to recover for "purely emotional" harm. ${ }^{245}$ The court characterized the women's harm as emotional, even though "many DES daughters have malformations of their cervixes and uteruses, as well as cellular changes to the vaginal and cervical lining"246 requiring extensive medical monitoring. A similar dynamic takes place when the effects of physical deformities arising from breast reduction or enlargement surgeries are treated by the courts primarily as emotional injuries. ${ }^{247}$ Finley's research on women's reproductive and sexualized injuries reinforces the basic feature of the conceptual vicious cycle, showing that the characterization of the nature of an injury is an active process capable of being influenced by the gender of the person suffering harm.

${ }^{242}$ These texts typically contain a separate section on negligent infliction of mental distress, discussing some cases in which the plaintiffs suffer physical as well as mental injuries. See, e.g., FRANKLIN \& RABIN, supra note 139, at 226-27 (discussing "emotional harm" cases); KEETON ET AL., supra note 1, at 359-66 (discussing "mental disturbance" cases). Students are often confused by the organization until they discover that "mental distress" cases is a reference to cases in which the mechanism of harm is fright or mental disturbance, rather than a reference to cases in which plaintiffs suffer only mental distress as a consequence of the event.

${ }^{243}$ See Finley, supra note 155, at 858-67.

24 Id. at 860.

245437 N.E.2d 171, 190 (Mass. 1982).

${ }^{246}$ Finley, supra note 155, at 860 .

${ }^{247}$ See id. 


\section{B. Property/Relational}

When a loss is experienced by a man, the law highlights its tangible and objective aspects and downplays its intangible and relational features. The transformation which occurred with respect to the claim for loss of spousal consortium ${ }^{248}$ suggests the operation of the conceptual vicious cycle. For as long as the claim was given exclusively to husbands, it was regarded as a property right. Under this "material version" of the loss of consortium, it was said that the husband owned the services of the wife, in much the same way that the master owned the services of his servant. ${ }^{249}$ It did not matter that domestic services performed by a wife generally had no market value and that, unlike the servant, the wife received no wages. When the law gradually evolved to permit the husband to claim loss of sex and society, in addition to loss of household services, there was no immediate change in the categorization of the harm. ${ }^{250}$ Nor was there a cognitive shift after the passage of the earnings statutes which first afforded married women legal rights to the fruits of their own labor. ${ }^{251}$ Instead, the one-sided property right in the husband persisted even with the erosion of coverture. Faced with the incongruity of a husband's claim for loss of his wife's labor, the courts drew a distinction between paid wage labor, which now belonged to the female worker, and unpaid household labor, which remained the property of the husband. Loss of services could thus still be claimed as an element in the husband's claim for loss of his wife's consortium. Even though the claim clearly encompassed material and intangible elements, it survived as a property right until well into the twentieth century. ${ }^{252}$ As

${ }^{248}$ See Katharine Silbaugh, Tuming Labor into Love: Housework and the Law, $91 \mathrm{NW}$. U. L. REV. 1, 41-44 (1996) (discussing the transformation of consortium from a property-based tort to a relational injury).

${ }^{249}$ See Kevin Lindsey, Note, A More Equitable Approach to Lass of Spousal Consortium, 75 IOWA L. REv. 713, 713 (1990) ("The wife's legal status was akin to that of a servant, [which] rendered her the property of her husband.").

${ }_{250}$ See Silbaugh, supra note 248 , at 42 (noting that the husband "retained the ability to bring a loss of consortium action for both society and services, with society being derivative of his right to domestic services").

${ }^{251}$ See Reva B. Siegel, The Modernization of Marital Status Law: Adjudicating Wives' Rights to Earnings, 1860-1930, 82 GEO. L.J. 2127, 2181 (1994) ("[C]ourts interpreting the earnings statutes stubbornly resisted the notion that wives might under any circumstance be the owners of their own labor.").

${ }^{252}$ The turning point came in 1950 when the D.C. Circuit first expanded the claim to wives. See Hitaffer v. Argonne Co., 183 F.2d 811, 820 (D.C. Cir. 1950). The court refused to separate the material (services) from the sentimental (love, affection, companionship, sexual relations) elements of the consortium claim, and thus held the 
long as the consortium claimant was male, the claim was not discredited for being intangible or relational.

In its contemporary gender-neutral form, however, loss of spousal consortium falls under the category of relational harm. The courts are split as to whether economic harm from loss of services is still encompassed within the claim. In its new "sentimental version," loss of spousal consortium is now precariously positioned as the only relational injury which carries protection against negligent interference. ${ }^{253}$ As such, it is vulnerable to the criticisms levied at other relational torts which have found little acceptance in the courts. Because the property-like features of the claim disappeared when the claim was given to female plaintiffs, the claim lost the privilege traditionally afforded to property. Because it is no longer gendered male, the injury has fallen in rank in the hierarchy. The history of this tort suggests that what constitutes a "material" loss depends on the status of the "property" owner.

\section{Economic/Noneconomic}

Perhaps the most clear-cut example of the operation of the conceptual vicious cycle is the valuation of household services, sometimes called "homemaker" services. For some time, feminists have observed that work done predominantly by women may not be classified as "work." Until quite recently, the law placed no economic value on a homemaker's domestic services, a category which encompasses not only cleaning the house, but also caring for children and other dependents. ${ }^{255}$ This dramatic undervaluation of women's work has had

wife's claim to be valid, even though it did not encompass a material element. See id. at 813. However, even in its new, nongendered form, the husband still owned both his wife's services and his own household labor. The final equalization would not occur until the wife was accorded the right to recover for her own household labor.

${ }^{253}$ See supra note 149. Claims for negligent interference with the parent/child relationship are recognized by only a minority of states. See supra note 151 .

${ }^{254}$ See Finley, supra note 88, at 52-54 (noting that homemaking activities are rarely appropriately compensated for in damage awards); Graycar, supra note 187, at 91 (noting a central "concern with women's work, and the question of whether it is to be recognized as having economic value ${ }^{n}$ ).

${ }_{255}$ Most studies regard the following tasks as housework: preparing meals, washing dishes, house cleaning, outdoor tasks, shopping, washing and ironing, paying bills, auto maintenance, driving, and child care. See, e.g., Silbaugh, supra note 248 , at 11. Substantially more than half of women's working hours are spent on housework, while less than a quarter of men's are so spent. See id. at 10. 
consequences not only for distribution of assets upon divorce, ${ }^{256}$ when homemakers tried to demonstrate their contributions to the marriage, but also has played a significant role in tort cases for wrongful death and personal injury. ${ }^{257}$

Several of the final reports of gender bias task forces have discussed the continued devaluation of homemaker services and the effects of such devaluation on stay-at-home mothers, employed women, and men. Plaintiffs' attorneys believe that juries harbor negative stereotypes about the value of housework and impose artificial ceilings on the value of a homemaker's life. ${ }^{258}$ There is even some evidence that, for comparable injuries, employed women receive higher damage awards for pain and suffering than homemakers, suggesting that negative attitudes towards this kind of work carry over to affect other elements of damages. ${ }^{259}$ The devalued status of household services is a form of gender-linked devaluation that reduces awards for employed women and men as well. Working mothers are often awarded paltry sums for their duties as homemakers, ${ }^{260}$ and the household tasks that men perform are sometimes invisible, ${ }^{261}$ reminiscent of the old common fiction that the wife loses nothing of material value when her husband is injured.

${ }^{256}$ For an argument that housework is either not valued or undervalued in divorce, see $i d$. at $56-67$.

${ }^{257}$ The failure to value women's work in the home is also evidenced by the reluctance of some courts to allow compensation for gratuitous home-based nursing services when they are provided to accident victims by relatives. See supra note 190 . It is disproportionately women who provide such services to family members and others. See supra note 185.

${ }^{258}$ See, e.g., Gail D. Cox, Juries Place Less Value on Homemakers, NAT'L L.J., Sept. 14, 1992, at 1,37 (noting that the valuation of the life of a homemaker is considerably less than it is for women who are employed outside the home, with a ceiling of approximately $\$ 450,000$ ).

${ }^{259}$ See NEW YORK TASK FORCE ON WOMEN IN THE COURTS, REPORT OF THE NEW YORK TASK FORCE ON WOMEN IN THE COURTS 128 (1986), published in 15 FORDHAM URB. L.J. 11, 81 (1986-1987) (citing a survey of attorneys in which more respondents perceived that women working outside the home got higher awards).

${ }^{260}$ See, e.g., FINAL REPORT OF THE MINNESOTA SUPREME COURT TASK FORCE FOR GENDER FAIRNESS IN THE COURTS 77 (1989) (stating that "[ $t]$ here is clear consensus ... that homemakers receive less than the economic value of their services"), published in 15 WM. MITCHELI L. REV. 825, 914-15 (1989); ILIINOIS TASK FORCE, supra note 12, at 186-92 (stating that a "typical female plaintiff will collect a smaller award for lost future income").

261 See WiSCONSIN EQUAL JUSTICE TASK FORCE, FINAL REPORT 28-29 (1991) (noting that while Wisconsin model jury instructions account for the value of the household tasks of a deceased wife, "[n]o such measure exists for a deceased husband who may have provided [such] services," and recommending the use of gender-neutral language in the provision). 
It is not surprising that what is classified as "economic" is tied to the market, leaving women undervalued in the domestic sphere of the home and family. The recently erected hierarchy of damages is a more subtle way of using men's activities as the sole benchmark of value.

\section{CONCLUSION}

There is less discussion these days about the redistributive potential of tort law. Perhaps we have given up on the idea that the tort system can be used as a force for creating equality. By excavating the deep structures of bias in tort law, I am suggesting a more modest goal. We should not accept the basic tort categories as neutral, static, and essential. Instead, before making important decisions, we should interrogate tort categories to assess their disparate impact on women, racial minorities, and other less privileged groups in our society. We should also become more attuned to the way our categories are already influenced by the gender or race of the victims.

I am particularly critical of the implicit hierarchy of types of injuries. The current skepticism toward compensation for emotional and relational harms is disproportionate: It discounts the importance of these injuries in the lives of tort victims and places too much emphasis on general fears of unlimited liability and concerns about difficulties of administration. This is not to say that all claims for genuine mental distress or demonstrable injuries to human relationships ought to be compensable in tort. We need some workable limitations on liability. My quarrel with the current system is that, through reliance on the implicit hierarchies, we are apt to shortcut difficult judgments about which claims deserve legal recognition, simply by presuming that certain types of injuries, on a categorical basis, are less worthy. If, as I contend, the basic categories of physical injury, property damage, emotional harm, and relational harm are themselves infected with gender and race bias, we should be wary of such categorical thinking.

Similarly, the recent movement to discredit awards of nonpecuniary damages and to solidify a hierarchy of type of damages which further privileges economic loss seems misguided. Tort reform should further objectives other than the impulse to downsize awards by targeting the noneconomic component of tort judgments. The recognition of noneconomic loss, like the partial acknowledgment of emotional and relational harms, is one feature of the current system that ameliorates bias against women and racial minorities. We should 
hesitate before enacting reforms that will intensify the disparate impact on nonprivileged groups, and instead consider reforms that counteract the implicit biases in the system. If caps on recovery are still thought to be desirable, for example, a more appropriate target might be loss of future earning capacity, a component of the damage award that has a greater impact on plaintiffs from more privileged groups.

My goal in this Article, however, is not to endorse or resist specific proposals for tort reform. Instead, my points are more general. I believe it is desirable to develop the habit of routinely assessing the differential effects of tort rules, to be cognizant that basic legal categories are social constructions that are tainted by gender and race bias, and to advocate gender and race equity as an independent goal of our torts compensation system. I wish to expose the hierarchies of values in the hope that, once they are made more visible, we will not be so impressed with what we see. 
